\title{
Were the Deccan Flood Basalts Derived in Part from Ancient Oceanic Crust Within the Indian Continental Lithosphere?
}

\author{
Hetu C. Sheth \\ Department of Earth Sciences, Indian Institute of Technology (IIT) Bombay, Powai, Bombay - 400 076, India, \\ E-mail:hcsheth@iitb.ac.in
}

(Manuscript received February 18, 2004; accepted October 19, 2004)

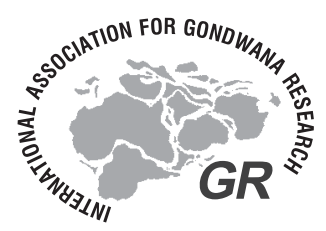

\begin{abstract}
Deep mantle plumes supposedly incorporate deeply subducted eclogitized oceanic crust, and continental flood basalts (CFBs) are now thought by some to be derived from such eclogite-bearing peridotite plumes. Eclogite-peridotite mixtures have much lower solidi (and produce much greater melt fractions for a given temperature) than peridotite. Ferich (eclogite- or pyroxenite-bearing) sources have been inferred for many CFBs. However, plumes with considerable amounts of eclogite should have difficulty in upwelling owing to the high density of eclogite. Besides, CFBs are always located along pre-existing lithospheric structures (suture zones, edges of thick cratons) and commonly associated with lithospheric rifting and continental breakup. India's major late Mesozoic CFB, the Deccan Traps, erupted through rift zones and a new continental margin that had developed along ancient suture zones traversing the subcontinent. Many Deccan basalts are too Fe-rich to have been in equilibrium with a peridotite mantle source, and have commonly been considered to be significantly fractionated derivatives of picritic liquids. However, it is possible to view them as relatively less evolved liquids derived from a source with extra fertility (i.e., an Fe-rich source). A new non-plume, plate tectonic model for Icelandic hotspot volcanism involves melting of a shallowly recycled slab of eclogitized Iapetus oceanic crust formerly trapped along the Caledonian suture. The model explains the geochemical-petrological characteristics of Icelandic basalts, and is consistent with passive upper mantle upwelling under Iceland inferred from recent seismic tomography. Based on the petrological and geochemical features of the Deccan flood basalts of the type section, in the Western Ghats, I propose that old, eclogitized oceanic crust trapped in the ancient Indian suture zones could have produced voluminous basaltic melts during the Deccan event.
\end{abstract}

Key words: Deccan volcanism, flood basalt, Iceland, eclogite, mantle plume.

\section{Introduction: Flood Basalt Genesis in the Mantle Plume Model}

The mantle plume initiation model for the origin of continental flood basalts (CFBs) (Richards et al., 1989; Campbell and Griffiths, 1990), has been widely accepted. The model postulates that intraplate, "hotspot" volcanism is caused by mantle plumes - abnormally hot upwellings that originate at the core-mantle boundary. The model is largely based on fluid dynamical experiments, which show that plumes should develop large "heads" by entrainment of surrounding mantle as they rise through the mantle, and the heads remain connected to the source region by narrow, pipe-like "tails". A plume head produces voluminous flood basalts, whereas a plume tail produces hot picritic melts. The model has been widely applied to the Deccan Traps of India, one of the largest and best examples of CFBs in the world (see Sheth, 2005 and references therein). The mainstream view is that (i) the currently active Réunion hotspot on the African plate represents the tail phase of a deep mantle plume, and (ii) the Deccan Traps originated from the head of the same plume during late Cretaceous time when the Indian subcontinent was drifting over it. This widely accepted model has been questioned on various grounds, however (Burke, 1996; Sheth, 1999a, b, 2000, 2005).

The original plume model (Richards et al., 1989; Campbell and Griffiths, 1990), which assumed a peridotititic mantle plume, was subsequently revised. Cordery et al. (1997) found it impossible to produce the observed amounts of magma in CFBs by melting peridotitic mantle alone, and argued that mantle plumes must contain significant amounts of eclogite to be able to melt sufficiently. Eclogite (and pyroxenite) melt at much lower temperatures than peridotite (e.g., Yasuda et al., 1994, 1997; Hirschmann and Stolper, 1996). Eclogite is essentially a bimineralic rock made up of garnet and clinopyroxene (omphacite), and accessory minerals like rutile, quartz, kyanite etc. (see Jacob, 2004 and references 
therein). It is the high-pressure equivalent of basalt, and is most typically formed in subduction zones by transformation of downgoing oceanic crust (e.g., Ito and Kennedy, 1971). Plumes are now thought to constitute eclogite-peridotite mixtures, and the eclogite component required in plumes is hypothesized to represent recycled oceanic crust subducted as far down as the base of the mantle (Cordery et al., 1997), to satisfy the perceived deep (plume) origins for CFBs. Pyroxenites have been defined as ultramafic rocks made up of pyroxenes without or with olivine, the modal olivine content not exceeding 40\% (Streckeisen, 1973). Pyroxenites in the sub-lithospheric mantle may also represent subducted oceanic crust (e.g., Allègre and Turcotte, 1986), and have a large range of major element compositions between peridotites and basalts (Hirschmann and Stolper, 1996).

\section{The Alternative: Shallowly Derived Eclogite}

Whereas petrologists and geochemists favouring the plume model and invoking deep recycling of slabs cite seismic tomography data as evidence for deep subduction, some experts on seismic tomography (e.g., Dziewonski, 2003, 2005) find little or no evidence for deep slab subduction. Besides, with new data, many regions traditionally considered to be classic plume areas have begun to be attributed to non-plume, upper mantle processes (see www.mantleplumes.org). A prominent example is Iceland, where recent seismic tomography work (Foulger et al., 2000, 2001) has not detected a plume in the lower mantle, and found evidence for upper mantle origin and passive upwelling instead. Iceland is the world's classic ridge-centred "hotspot" and the only part of the global mid-oceanic ridge system that is subaerial.

It has been emphasized (e.g., Anderson, 1996; Foulger et al., 2005) that mantle temperature is not the only parameter controlling melt volumes generated; mantle fertility (garnet+clinopyroxene content) or the presence of volatiles are very important as well. It is not generally appreciated that large volumes of CFB do not uniquely require high absolute temperatures. It is the temperature relative to the local solidus that is important, as well as the volume of mantle sampled, focussing effects, etc. (D.L. Anderson, pers. comm., 2004). The idea of a not-so-hot but extra-fertile source for flood basalts therefore deserves serious consideration. The anomalously thick $(30 \mathrm{~km})$ crust under Iceland and many unusual petrological-geochemical features of Icelandic basalts have been explained by melting of eclogite-bearing peridotite (e.g., Chauvel and Hemond, 1999; Korenaga and Kelemen, 2000), and the eclogite has recently been proposed to represent not a deeply derived plume but a shallowly recycled slab of the Iapetus oceanic crust that was subducted (and partly trapped) when the continents of Laurentia, Baltica and Avalonia collided to form the Caledonian Suture at $440 \mathrm{Ma}$ (Foulger and Anderson, 2005; Foulger et al., 2005). Warm slabs do not subduct deeply but can become neutrally buoyant at shallow depths (Oxburgh and Parmentier, 1977), and if the supercontinent above subsequently rifts apart, the eclogitic slabs, if still warm, can be entrained in the rifting-induced mass upwelling and undergo voluminous melting at normal mantle temperatures, producing much thicker crust than would be possible to get by melting peridotite alone.

In the case of CFBs too, before placing the required eclogitic source in the deep mantle, the potential availability of eclogite at shallow, upper mantle depths beneath the continents must be evaluated. The continents are geologically, structurally, and geophysically far more complex than the ocean floors. Addressing the fundamental structure and geological history of the continent in question is thus essential. Here, I propose that the mantle source of the voluminous Deccan lavas was not solely peridotite but included a basaltic component (eclogite). I also propose that, as at Iceland, the eclogitic component was not derived from a deep mantle plume but represents slabs of ancient oceanic lithosphere trapped in the old suture zones that traverse the Indian Precambrian shield.

\section{Structure and Tectonics of the Indian Shield}

India is one of the oldest continents, and has a very rich rock record from the Archaean up to the Recent. At least six Archaean to early Proterozoic cratonic nuclei, and several fold belts, are recognized in India (Naqvi and Rogers, 1987). The nuclei may have been sutured together in Archaean-Proterozoic time by proto-plate tectonic processes (e.g., Naqvi et al., 1974; Radhakrishna, 1989; but see Hamilton, 1998 for a contrary view). Several major rift zones traverse the Indian Peninsula (Fig. 1): the Godavari and Mahanadi rifts in the east, the Cambay rift in the north, the Kachchh rift in the northwest, and the E-W-trending Narmada and Tapi rifts, enclosing the Satpura horst-block in between (e.g., Biswas, 1987). Three major CFB provinces formed in India and its contiguous landmasses and oceans during the Mesozoic, all associated with continental breakup. The Deccan CFB event was associated with the breakup of India from the Seychelles microcontinent at $\sim 65$ Ma (e.g., Mahoney, 1988; Fig. 1 inset). Prior to this, the Indo-Madagascar province formed along with the breakup of Madagascar from Greater India (India plus Seychelles) at $\sim 88 \mathrm{Ma}$ (Storey et al., 1995, 1997; 
Anil Kumar et al., 2001; Pande et al., 2001). Still earlier, the Rajmahal-Sylhet CFB formed at 116-120 Ma, about 10 million years after the breakup of eastern Greater India from Australia (e.g., Kent et al., 1997). The newly formed continental margins, and the rift zones, constituted major vent areas for the Deccan CFB, as inferred from abundant mafic dyke swarms and intrusions, high heat flow, and aligned thermal springs (e.g., Sheth, 2000, 2005).

The Indian rifts run along major Precambrian tectonic trends (Katz, 1978). The Narmada zone in particular is a prominent, ancient line of weakness and has been proposed to be a Proterozoic protocontinental suture between a northern, Aravalli protocontinent and a southern, Dharwar protocontinent (Naqvi et al., 1974; Radhakrishna, 1989). The Cambay rift, and the western continental margin of India, also developed by faulting parallel to the NNW-SSE Dharwar orogenic trend of Precambrian age (Biswas, 1987), i.e., India may have broken off from Seychelles, and Greater India from Madagascar, along what were apparently terrane boundaries. Another major Precambrian orogenic trend, the NE-SW Aravalli trend, splays out into two at its southern end: the E-W Delhi trend (along which the Kachchh rift has developed), and the main NE-SW Aravalli trend which continues right across the Cambay rift into Saurashtra (Fig. 1; Biswas, 1987).

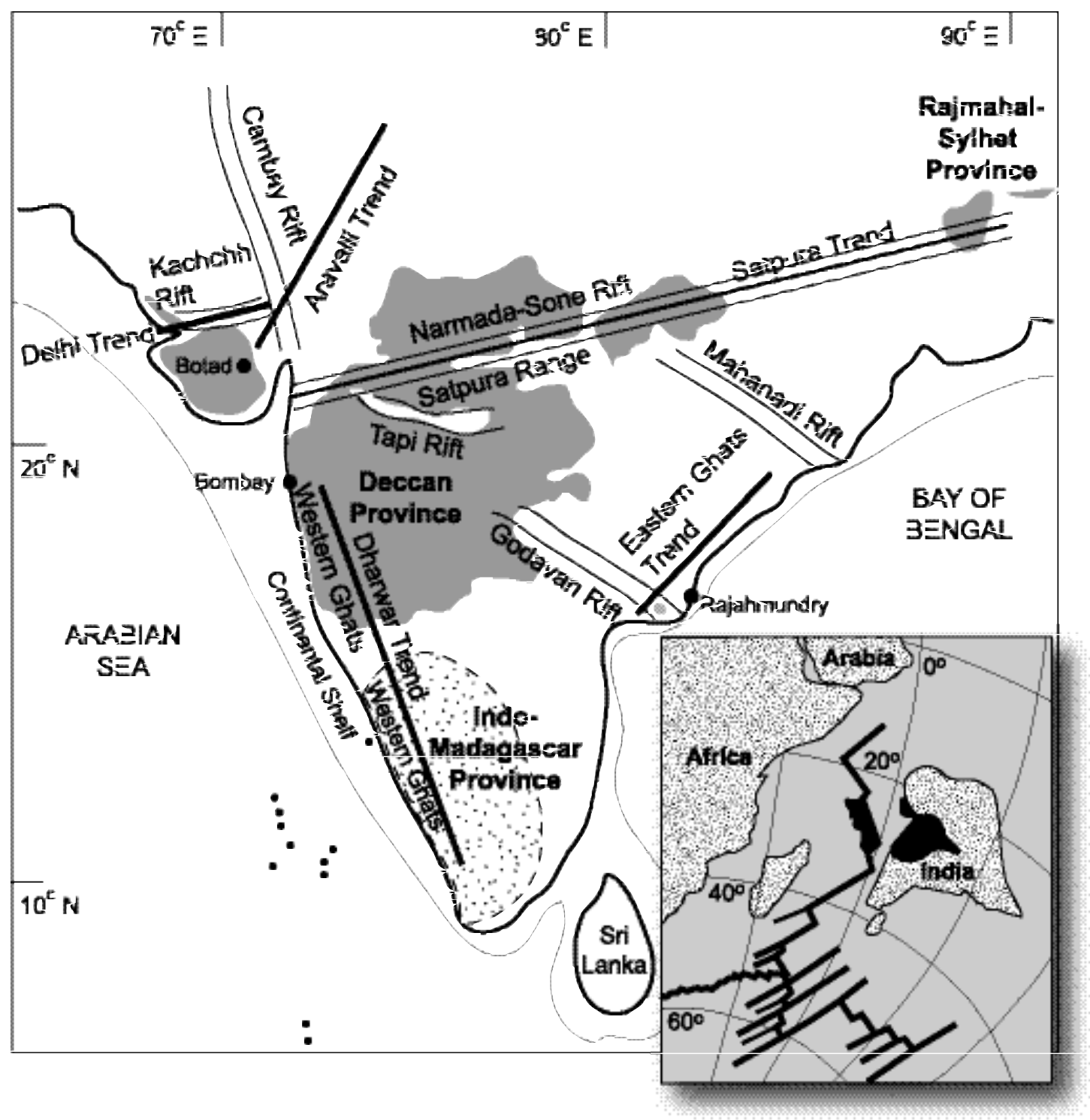

Fig. 1. Map of India showing the outcrop area of the Deccan and Rajmahal Traps (dark gray), the Indo-Madagascar province (stippled), the rift zones underlying the Deccan, the Precambrian structural trends, and some localities. The Indo-Madagascar province in India is represented mostly by dykes and minor volcanics. Based on Biswas (1987) and Sheth (2000). Inset shows the breakup of the Seychelles microcontinent from India at $\sim 65$ Ma due to a ridge jump (Norton and Sclater, 1979), at which time Deccan flood volcanism (black areas) took place. 


\section{The Deccan Tholeiites and Picrites}

The Deccan lava pile is spectacularly exposed in the southwestern part of the province (Fig. 1) in the Western Ghats (Sahayadri) range, and the stratigraphic framework of this region is now known quite well from extensive field, geochemical (including isotopic) and palaeomagnetic work (e.g., see Mahoney, 1988 and references therein; Subbarao, 1988 and references therein; Lightfoot et al., 1990; Peng et al., 1994). The Western Ghats sequence is almost exclusively tholeiitic (subalkalic) (Fig. 2), with a stratigraphic thickness of $\sim 3,000 \mathrm{~m}$, and on the basis of geochemical characteristics and field markers, has been divided into three subgroups and eleven formations (Table 1). The Jawhar and Igatpuri are actually two separate formations with very similar geochemistry and petrogenetic evolution (see Subbarao, 1988 and references therein), and are therefore often grouped together. There is also no consensus regarding the formation status of the Desur, originally defined as a unit of the Panhala Formation.

Many of the formations have been subdivided into members and chemical types. Crustal contamination was a common process in the evolution of the Deccan basalts, and several distinct crustal end members were apparently involved, as attested by the arrays defined by the various formations in $\mathrm{Nd}-\mathrm{Sr}-\mathrm{Pb}$ isotopic ratio plots (Fig. 3). Table 1 , based on Peng et al. (1994), lists the age-corrected (to $66 \mathrm{Ma}$ ) ${ }^{87} \mathrm{Sr} /{ }^{86} \mathrm{Sr}$ ratios of the basalts. Unlike most formations, the Ambenali Formation lavas are relatively little contaminated by continental lithospheric materials, with age-corrected $\varepsilon \mathrm{Nd}$ values of about +3 to +7 , and the Mahabaleshwar Formation lavas appear to be affected by either lithospheric mantle or old granulitic crust with

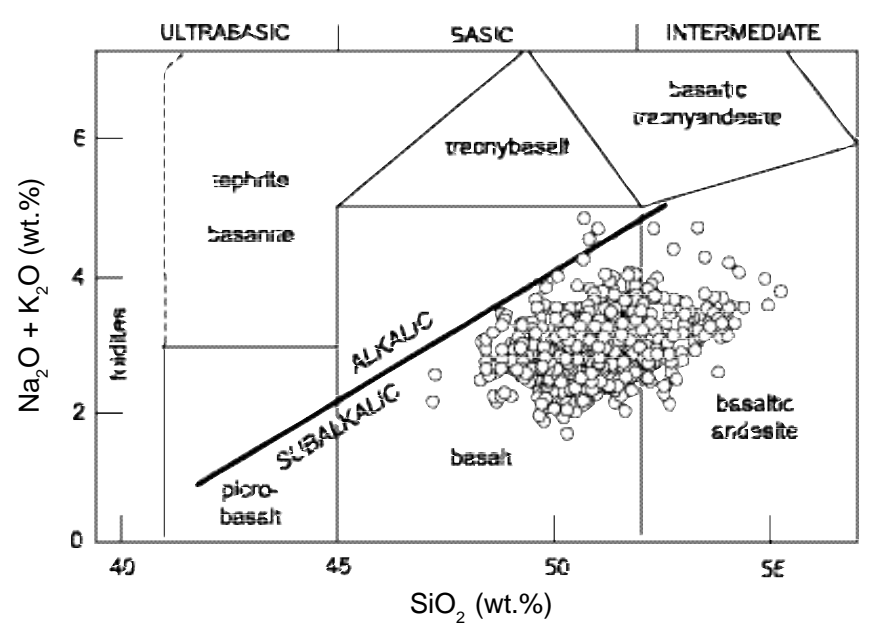

Fig. 2. Total alkali-silica diagram (Le Bas et al., 1986), showing that nearly all Western Ghats lavas (624 samples, Beane, 1988) are subalkalic basalts and basaltic andesites. Heavy diagonal line (after Macdonald and Katsura, 1964) separates the alkalic and subalkalic fields.
Table 1. The southwestern Deccan formation stratigraphy, and ranges of age-corrected Sr isotopic values for the various formations.

\begin{tabular}{|c|c|c|c|}
\hline Group & Subgroup & Formation & $\left({ }^{87} \mathrm{Sr} /{ }^{86} \mathrm{Sr}\right)_{\mathrm{t}}=66 \mathrm{Ma}$ \\
\hline \multirow{11}{*}{$\begin{array}{l}\text { Deccan } \\
\text { Basalt }\end{array}$} & \multirow{5}{*}{ Wai } & $\operatorname{Desur}(\sim 100 \mathrm{~m})$ & $0.7072-0.7080$ \\
\hline & & Panhala (>175 m) & $0.7046-0.7055$ \\
\hline & & Mahabaleshwar (280 m) & $0.7040-0.7055$ \\
\hline & & Ambenali $(500 \mathrm{~m})$ & $0.7038-0.7044$ \\
\hline & & Poladpur $(375 \mathrm{~m})$ & $0.7053-0.7110$ \\
\hline & \multirow{2}{*}{ Lonavala } & Bushe $(325 \mathrm{~m})$ & $0.7078-0.720$ \\
\hline & & Khandala $(140 \mathrm{~m})$ & $0.7071-0.7124$ \\
\hline & \multirow{4}{*}{ Kalsubai } & Bhimashankar (140 m) & $0.7067-0.7076$ \\
\hline & & Thakurvadi $(650 \mathrm{~m})$ & $0.7067-0.7112$ \\
\hline & & Neral $(100 \mathrm{~m})$ & $0.7062-0.7104$ \\
\hline & & Jawhar-Igatpuri (>700 m) & $0.7085-0.7128$ \\
\hline
\end{tabular}

very low ${ }^{206} \mathrm{~Pb} /{ }^{204} \mathrm{~Pb}$. Thick lava piles that closely resemble (chemically and isotopically) many of the Western Ghats formations, besides lava flows and dykes with compositions unlike any seen in the Western Ghats, are now known from widely spaced sections in the Deccan province (e.g., Peng et al., 1998; Mahoney et al., 2000; Sheth et al., 2004).

Intercalated basalt and picritic basalt flows are known from boreholes in the northwestern Deccan (around Botad, Fig. 1). These were postulated by Campbell and Griffiths (1990) to be high-temperature, high-meltfraction picritic liquids derived from the axis of their conjectured plume. The picritic lavas are rich in olivine $\left(\mathrm{Fo}_{87-90}\right)$ and clinopyroxene phenocrysts, though close to being primary magmas with $\sim 16$ wt. $\% \mathrm{MgO}$ (Krishnamurthy and Cox, 1977). Such liquids cannot themselves be produced from an eclogitic (olivine-free) source, because it would have less $\mathrm{MgO}$ than the magmas themselves. The volatile content of the source of these picritic liquids is also unknown, but $\mathrm{H}_{2} \mathrm{O}$ and $\mathrm{CO}_{2}$ significantly reduce the mantle solidus (e.g., Green, 1973; Hirose and Kawamoto, 1995; Gaetani and Grove, 1998). These lavas are also known to be mildly alkalic, and are therefore not the high- $F$ picrites Campbell and Griffiths (1990) pictured them to be. Peng and Mahoney (1995), in a Nd-Sr-Pb isotopic and trace element study of these rocks, identified two distinct mixing arrays. One was postulated by them to reflect mixing between a mantle end member very similar to that for modern Réunion Island lavas, and a high- ${ }^{208} \mathrm{~Pb} /{ }^{204} \mathrm{~Pb}$, high- ${ }^{207} \mathrm{~Pb} /{ }^{204} \mathrm{~Pb}$ continental lithospheric end member. The second trend was argued by them to reflect mixing between the same continental lithospheric material and a mantle end member resembling the thick Ambenali Formation of the Western Ghats, taken by many to represent the composition of the Deccan plume head. Peng and Mahoney (1995) found, however, that both the mixing arrays include picritic members (i.e., picritic rocks were 


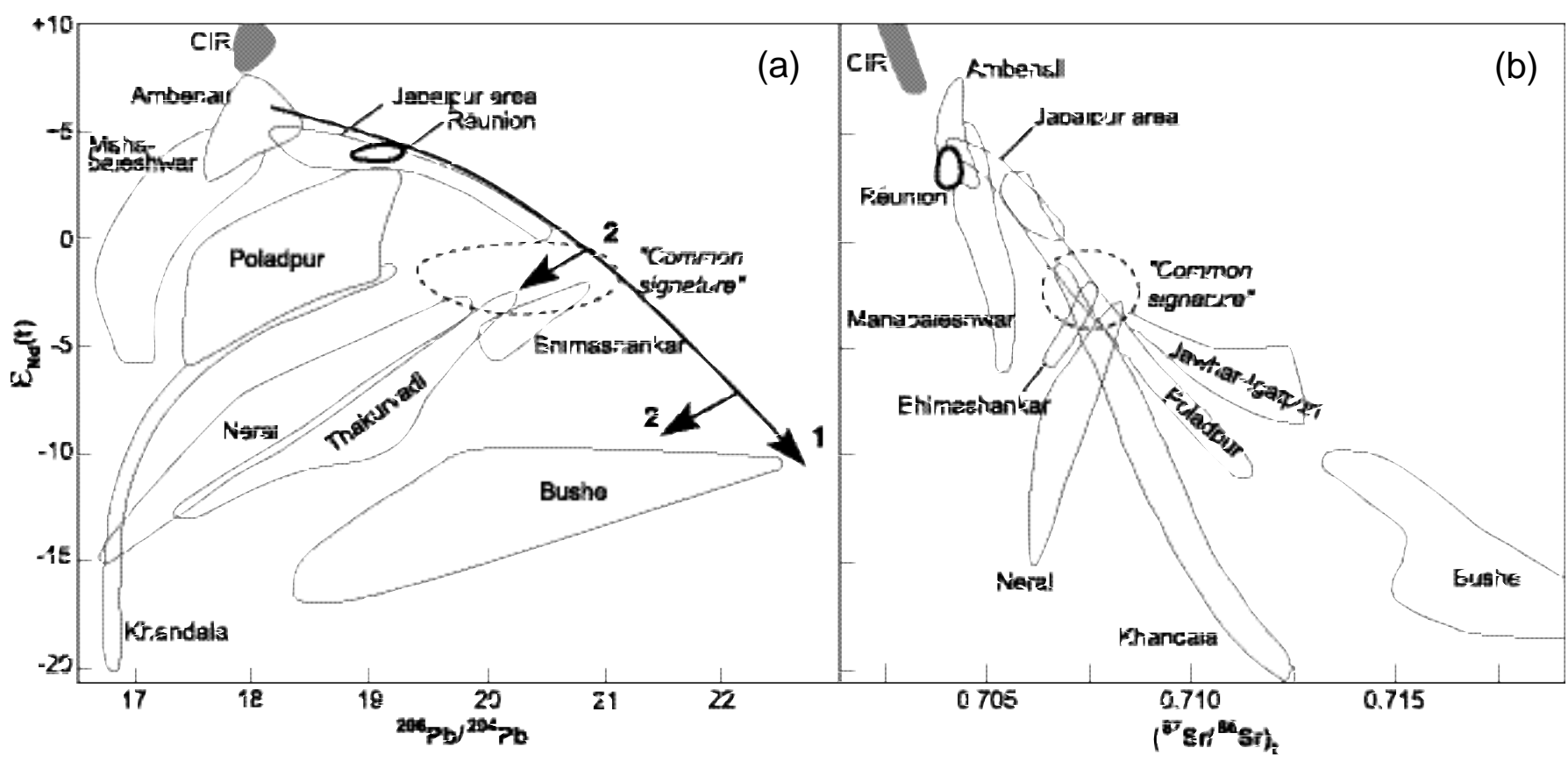

Fig. 3. (a) Fields of initial $\varepsilon \mathrm{Nd}(\mathrm{t}) \mathrm{vs} .{ }^{206} \mathrm{~Pb} /{ }^{204} \mathrm{~Pb}$ for individual Deccan formations from the Western Ghats. (b) Fields of initial $\varepsilon \mathrm{Nd}(\mathrm{t}) \mathrm{vs}$. $\left({ }^{87} \mathrm{Sr} /{ }^{86} \mathrm{Sr}\right) \mathrm{t}$ for these formations. $t=66$ Ma. Fields are also shown for present-day Central Indian Ridge (CIR) N-MORB and Réunion Island. Based on Peng et al. (1994) and Mahoney et al. (2000). The field for Jabalpur lavas is from Peng et al. (1998). The thick arrows marked 1 and 2 show the two stages of magma-lithosphere mixing conceived by Peng et al. $(1994,1998)$.

not confined to the mixing array involving the Réunion component alone), and the most isotopically Réunionlike lavas were in fact non-picritic. This fact, and the suggestion from trace element data that they could be high-pressure, low- $F$ melts instead (Peng and Mahoney, 1995), is at variance with Campbell and Griffiths' (1990) picture of the Deccan plume.

Few occurrences of picritic rocks are encountered also along the western part of the Narmada rift and in the Saurashtra peninsula, south of Botad (Melluso et al., 1995; Krishnamurthy et al., 2000). Cores of olivine phenocrysts in them are forsteritic $\left(\mathrm{Fo}_{86-92}\right)$, and phenocryst rims more Fe-rich. One sample (ANK) of Krishmurthy et al. (2000) has a olivine phenocryst rim composition $\mathrm{Fo}_{60}$ and groundmass olivines of $\mathrm{Fo}_{84-72}$ compositions. Another flow contains $\mathrm{Fo}_{83}$ phenocrysts and $\mathrm{Fo}_{64}$ groundmass olivines. Clearly, only some of these existed as picritic liquids, but many of them are mildly alkalic or transitional, rich in $\mathrm{TiO}_{2}$ (>1.8\%), $\mathrm{K}_{2} \mathrm{O}$ and $\mathrm{P}_{2} \mathrm{O}_{5}$ (Krishnamurthy et al., 2000). On the other hand, picritic basalts of the Western Ghats show a huge range in olivine compositions, $\mathrm{Fo}_{84-43}$ (Krishnamurthy et al., 2000), and the Western Ghats tholeiites have an average olivine composition $\mathrm{Fo}_{77}$ (Sen, 2001). The picritic basalts of the Western Ghats are enriched in cumulus olivine and clinopyroxene and do not represent liquid compositions (Beane and Hooper, 1988; Krishnamurthy et al., 2000). Most of the samples shown on figure 2 are quite evolved, with $\mathrm{MgO}$ in the range 4-7 wt.\%.

\section{Melting of Eclogite-Peridotite Mixtures}

Few experimental petrological data on the Deccan lavas exist. Sen (1988) studied some tholeiites from the Western Ghats that were nearly aphyric, and contained $9-10 \%$ $\mathrm{MgO}, 9-10 \% \mathrm{FeO}, 10-11 \% \mathrm{CaO}$, and $16-17 \% \mathrm{Al}_{2} \mathrm{O}_{3}$. $\mathrm{He}$ argued that they had undergone little or no olivine fractionation, and were likely generated from a heterogeneous but dominantly N-MORB-type mantle at $10-15 \mathrm{~kb}(\sim 35-50 \mathrm{~km})$. He suggested that the much more abundant and more evolved Deccan lavas (with 4-7 \% $\mathrm{MgO}$ ) are products of substantial gabbro fractionation. Later, he suggested (Sen, 1995) that the Deccan primary magmas were picritic and formed over the pressure range of 2 to $3 \mathrm{GPa}$.

An eclogite-bearing source has not been evaluated for the Deccan so far. If the eclogite-peridotite mixed source model is valid for the Deccan, it means that the large Deccan lava volumes produced and erupted were due to higher source fertility (garnet+clinopyroxene content), not high temperatures. Arguments for a large mantle thermal anomaly based on large erupted volume alone (e.g., White and McKenzie, 1989) can be discounted. Eclogite, like pyroxenite, has a much lower melting point than peridotite, and earlier work (Yoder and Tilley, 1962; Ito and Kennedy, 1974; Yasuda et al., 1994) also suggested a much narrower (as little as $75-100^{\circ} \mathrm{C}$ ) melting range for eclogite than peridotite (Fig. 4). Recent work (Yaxley, 
2000) indicates that eclogite and eclogite-peridotite mixtures can have a melting interval as wide as or wider than peridotite (Fig. 5a), displaced overall to significantly lower temperatures at all pressures. (Note, however, the liquidus minimum on figure $5 \mathrm{a}$, corresponding to a 30:70 wt.\% eclogite:peridotite mixture for which the melting interval is only $250^{\circ} \mathrm{C}$, compared to $400^{\circ} \mathrm{C}$ for the pure peridotite composition). During adiabatic upwelling of a mixed eclogite-peridotite source, the eclogite would melt earlier (at higher pressure) than the peridotite because its solidus temperature is considerably lower than that of peridotite, at least for upper mantle depths (e.g., Yasuda et al., 1994). This is in part because the effect of increased Fe and alkalis is to lower the solidus. Thus, the addition of basalt to peridotite reduces its solidus and liquidus, which results in melting beginning at a lower temperature in the basalt-peridotite mixture, and in melt fractions being higher for a given temperature (Fig. 5b). Compared to fertile peridotite, a mantle source consisting of $\sim 30$ wt.\% eclogite mixed with $\sim 70 \%$ peridotite has substantially higher melt productivity during adiabatic ascent in the upper mantle (Yaxley, 2000).

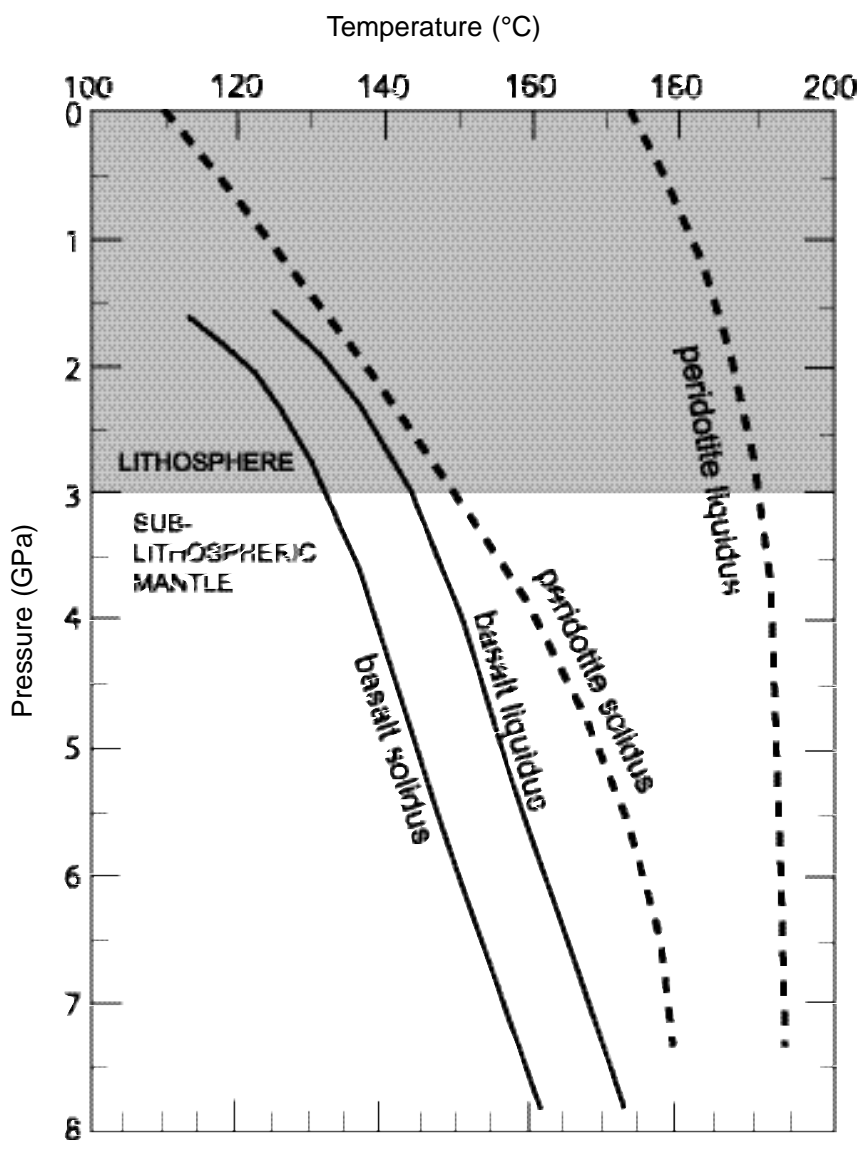

Fig. 4. Solidus and liquidus curves for anhydrous fertile peridotite (McKenzie and Bickle, 1988) and average MORB (Yasuda et al., 1994) in pressure-temperature space. Taken from Yaxley (2000).
I show below that the petrological characteristics of the Deccan tholeiites may be interpreted as indicating an excess basaltic component in their mantle source, with which many of their geochemical signatures are also consistent.

\section{An Fe-rich Source for the Thakurvadi Formation Lavas?}

Beane and Hooper (1988) described several flows from the Neral and Thakurvadi Formations that have apparently fractionated a mineral assemblage dominated by olivine. Olivine accumulation at the base of several of these flows, by crystal settling, is also clearly observed in outcrop. At Malshej Ghat, $125 \mathrm{~km}$ NE of Bombay, they observed that the bottom one metre of a flow unit is clearly enriched in olivine phenocrysts (1-3 $\mathrm{mm}$ in size), but the upper part of the unit is nearly aphyric. The olivine phenocrysts have cores as $\mathrm{Mg}$-rich as $\mathrm{Fo}_{84}$ and rims of $\mathrm{Fo}_{74}$, and an estimated average composition of $\mathrm{Fo}_{76}$. Beane and Hooper (1988) found that the picrite basalt layer (their sample SAM-017, with $15.63 \% \mathrm{MgO}$ ) can be derived by adding about $29 \%$ of the olivine phenocrysts to the aphyric sample, and calculated that the parental melts of these picrites (with which $\mathrm{Fo}_{84}$ olivine cores would be in equilibrium) would have contained $9-10 \% \mathrm{MgO}$. As noted by them, these liquids represent the most primitive liquids for which we have direct evidence in the Western Ghats, and such magmas cannot have been in equilibrium with mantle peridotite.

I performed calculations (Table 2) of incremental addition of equilibrium olivine to a whole-rock composition represented by the aphyric lava sample SAM018 of Beane and Hooper (1988). This sample can be interpreted as a "daughter liquid" (DL) of more magnesian magmas. I calculated thirty-five successive "parental liquid" (PL) compositions, each by adding $1 \mathrm{wt} . \%$ equilibrium olivine (Roeder and Emslie, 1970) to the previous liquid composition. Five of these parental liquid compositions, with which olivines containing 79.4, 83.9, 84.3, 90.0 and $91.0 \mathrm{Fo} \%$ respectively would be in equilibrium, are given. SAM-018 (DL) has a Mg\# value of only 52.6, where $\mathrm{Mg} \#=\left[\right.$ atomic $\left.\mathrm{Mg} /\left(\mathrm{Mg}+\mathrm{Fe}^{2+}\right)\right] \times 100$, assuming $\mathrm{Fe}^{3+} / \mathrm{Fe}^{2+}=0.16$. SAM-018 (DL) has equilibrium olivine with Fo\% of 78.7, and could be derived by 9 or $10 \mathrm{wt} . \%$ olivine fractionation from a parental magma represented by PL9 or PL10 respectively (equilibrium olivine in both is $\left.\sim \mathrm{Fo}_{84}\right)$. Peridotite-mantle-derived picritic primary magmas should crystallize equilibrium olivines with Fo\% $>90$ (typically 91), and should have whole-rock Mg\# values of 75 (Basaltic Volcanism Study Project, 1981). PL30 and PL35 are two such calculated parental liquids with $\mathrm{Fo}_{90}$ and $\mathrm{Fo}_{91}$ equilibrium olivine 


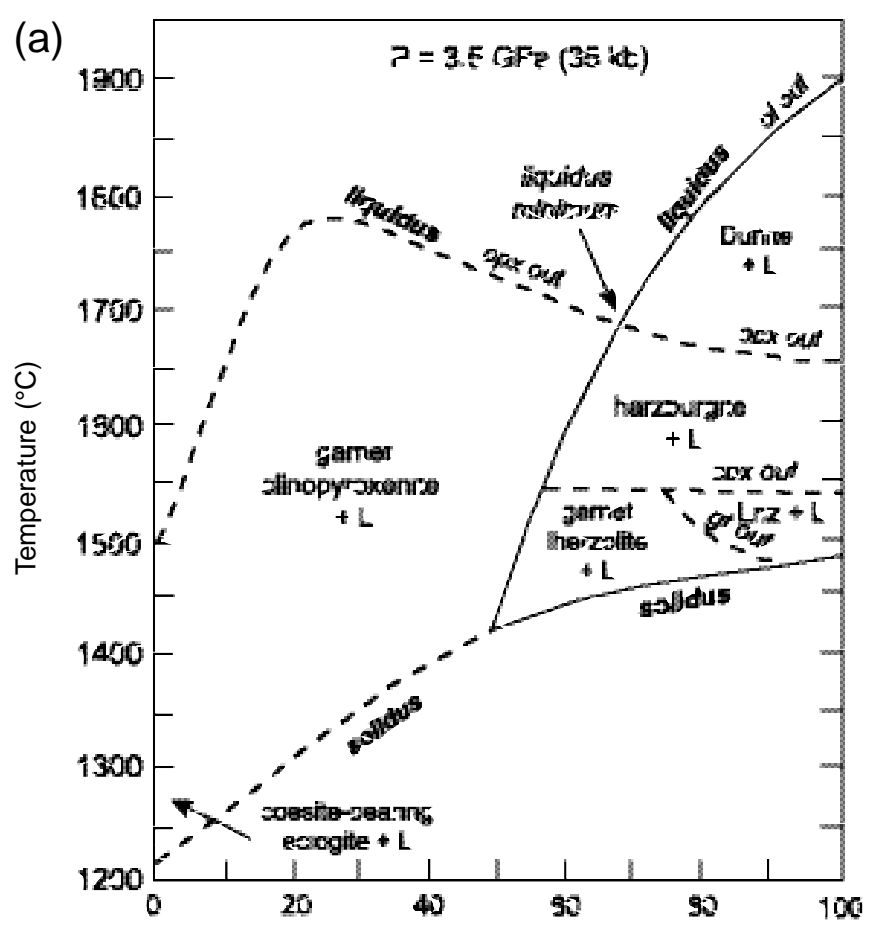

wt.\% peridotite in basalt-peridotite mixture

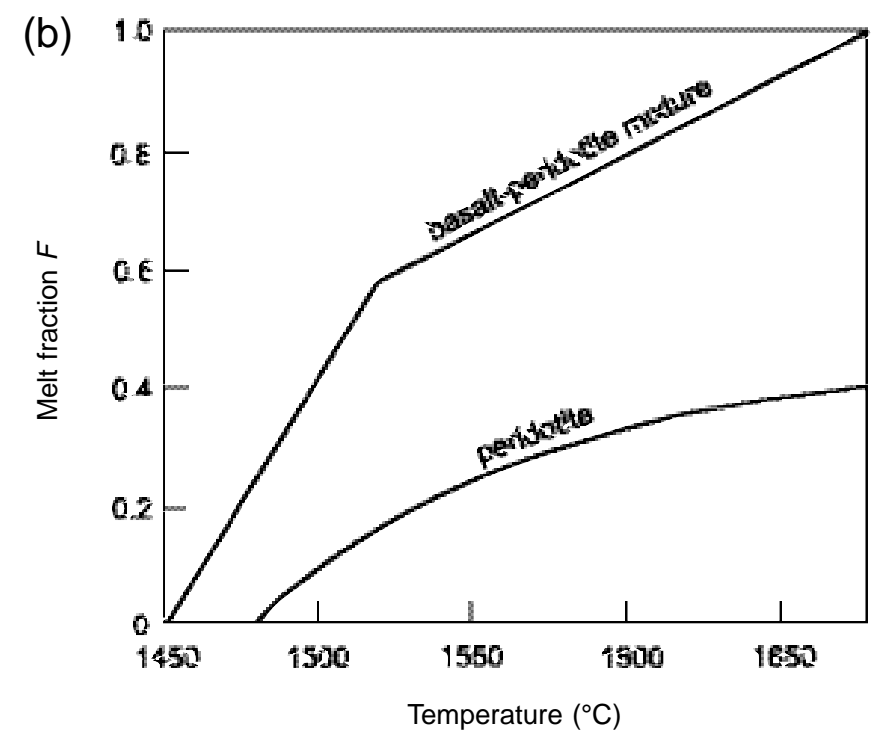

Fig. 5. (a) Phase relationships on the compositional join eclogiteperidotite. The specific samples studied are GA1 (average altered oceanic crust, Yaxley and Green, 1994) and MPY90 (peridotite), and their various mixtures. Whole-rock compositions of these can be found in Yaxley (2000). L=liquid; $\mathrm{gt}=$ garnet; $\mathrm{opx}=$ orthopyroxene; $\mathrm{cpx}=$ clinopyroxene; ol=olivine. (b) Curves of melt fraction $F$ vs. temperature for a 30:70 wt.\% mixture of average altered oceanic crust and fertile peridotite, and for pure peridotite. The peridotite curve is based on McKenzie and Bickle (1988), and the basalt-peridotite line is an approximate estimate for the liquidus minimum composition shown in (a). The higher average $d F / d T$ and lower solidus of the mixed rock results in much higher melt productivity compared to peridotite for a given temperature. After Foulger and Anderson (2005). respectively. Assuming that SAM-018 is derived by fractionation alone from a parental, primary magma like PL35, 35 wt.\% olivine fractionation is required. The required amount of fractionation is much more if clinopyroxene, plagioclase, and iron oxides were considered besides olivine, because these other minerals would deplete $\mathrm{MgO}$ in daughter liquids to a much lesser degree than olivine alone would. Huge piles of cumulates should then be expected in the subsurface under the Deccan. Cox (1980) indeed suggested extensive crustal or subcrustal sill complexes and cumulate layers, and strongly argued for the derivation of Deccan basalts from picritic parent liquids (Cox, 1999). He considered only a peridotite mantle source probable.

\section{Crustal Contamination, Peridotitic Source, or Eclogite-bearing Peridotite Source?}

The possibility suggested here is that Deccan lavas like SAM-018, in which the most magnesian olivine phenocryst cores are only $\mathrm{Fo}_{84}$, were derived from primary magmas that would crystallize equilibrium olivine with $84 \leq \mathrm{Fo} \%<<91$ compositions, i.e., primary magmas that were not in equilibrium with peridotite but were in equilibrium with a more Fe-rich source than peridotite. Note that the Fe-rich cores of olivines in these lavas cannot be ascribed to their having assimilated continental crust. There is agreement (e.g., Cox and Mitchell, 1988; Sen, $1995,2001)$ that crustal contamination of the Deccan basalts had a relatively minor effect on their major element compositions, which were instead largely controlled by fractional crystallization and magma mixing. If, therefore, the lavas with $\mathrm{Fo}_{84}$ olivine cores are not much fractionated (so near-primary), they are showing us the low olivine Fo content of the mantle source with which they equilibrated, which clearly would not be peridotite. Unfortunately, there is no way to prove that they are primary or near-primary. One has the choice here of interpreting them so, or as highly fractionated daughters of parental magmas with $\mathrm{Fo}_{91}$ olivines. For the former case, thick dunite layers in the subsurface are not required or expected, and for the latter case they are essential. High-resolution seismic studies might be able to image such dunite layers if they exist.

What then are the amounts of fractional crystallization likely to be undergone by the Deccan flood basalts? Plagioclase is a very common phenocryst in many, and olivine and clinopyroxene phenocrysts are by no means rare. Substantial gabbro fractionation at shallow depths is indicated (e.g., Mahoney, 1988; Sen, 1988, 2001 and references therein). I suggest that many of the Deccan basalt lavas, while they may be the result of gabbro fractionation, have undergone much less of early olivine 
Table 2. Calculated whole-rock and equilibrium olivine compositions for successive parental liquids of the lava SAM-018 (DL).

\begin{tabular}{lrrrrrr}
\hline Oxide wt. \% & \multicolumn{1}{c}{$\mathrm{DL}$} & \multicolumn{1}{c}{ PL1 } & \multicolumn{1}{c}{ PL9 } & PL10 & PL30 & PL35 \\
\hline $\mathrm{SiO}_{2}$ & 49.04 & 48.94 & 48.23 & 48.15 & 46.71 & 46.41 \\
$\mathrm{TiO}_{2}$ & 2.32 & 2.30 & 2.14 & 2.12 & 1.72 & 1.62 \\
$\mathrm{Al}_{2} \mathrm{O}_{3}$ & 15.05 & 14.90 & 13.74 & 13.60 & 11.10 & 10.55 \\
$\mathrm{FeO}(\mathrm{T})$ & 13.02 & 13.09 & 13.44 & 13.45 & 13.17 & 12.97 \\
$\mathrm{MnO}$ & 0.19 & 0.19 & 0.17 & 0.17 & 0.14 & 0.13 \\
$\mathrm{MgO}$ & 6.89 & 7.23 & 10.00 & 10.35 & 17.07 & 18.67 \\
$\mathrm{CaO}$ & 10.92 & 10.81 & 9.97 & 9.87 & 8.06 & 7.66 \\
$\mathrm{Na}_{2} \mathrm{O}$ & 1.90 & 1.88 & 1.72 & 1.70 & 1.35 & 1.30 \\
$\mathrm{~K}_{2} \mathrm{O}$ & 0.40 & 0.40 & 0.36 & 0.36 & 0.30 & 0.28 \\
$\mathrm{P}_{2} \mathrm{O}_{5}$ & 0.26 & 0.25 & 0.23 & 0.23 & 0.19 & 0.18 \\
$\mathrm{Total}$ & 99.99 & 99.99 & 100.00 & 100.00 & 99.81 & 99.77 \\
$\mathrm{Mg \#}$ & 52.6 & 53.6 & 60.9 & 61.8 & 73.0 & 75.2 \\
$\mathrm{Fo} \%$ & 78.7 & 79.4 & 83.9 & 84.3 & 90.0 & 91.0 \\
\hline
\end{tabular}

fractionation than would be required for melts of normal peridotite. What this means is that the primary magmas that were produced in the mantle were already Fe-rich compared to "normal" peridotite melts.

In the AFM diagram (Fig. 6), the Western Ghats lavas define a marked tholeiitic trend (Fe-enrichment). This trend does not, of course, mean an Fe-rich source. However, the relatively evolved, Fe-rich compositions of a large majority of the Deccan tholeiites have been hitherto interpreted as a result of advanced fractional crystallization. A relatively Fe-rich source (compared to normal peridotite) and the appropriate Fe-rich primary magmas, as argued here, would mean the following:

(i) Required amounts of fractional crystallization are relatively small. Yasuda et al. (1997) and Cordery et al. (1997) made the same argument, that the amounts of fractionation necessary to derive the erupted basalts from picritic parents could be significantly reduced if the mantle source (in their model an upwelling mantle plume) contained eclogite and the primary magmas were not picrites to begin with.

(ii) The volume of total magma generated is considerably smaller than that estimated from peridotite melting models. The latter require huge amounts of magma $(\geq 50 \%)$ to be not erupted but left as cumulates in the subsurface.

(iii)Even accepting that magma volume produced is related to mantle temperature alone (which is not correct), the lesser total magma volume that is produced in the new model makes a thermal anomaly still less necessary.

Recent experimental work (Yaxley, 2000) shows that hybrid basalt (eclogite)-peridotite mixtures with $<45 \pm 5$ wt. $\%$ of the basaltic component will produce primary melts that crystallize more Fe-rich olivine (Fo\% <89-90) than normal peridotite melts. A nearsolidus primary liquid in equilibrium with a source containing $\mathrm{Fo}_{84-85}$ olivine (a 45:55 eclogite:peridotite source) would contain $9-15 \% \mathrm{MgO}$, and a near-solidus primary liquid in equilibrium with a source containing $\mathrm{Fo}_{90}$ olivine (a peridotite source) would contain 16-22\% $\mathrm{MgO}$ (Yaxley, 2000). The former type of primary liquid is what Beane and Hooper (1988) calculated as a parental liquid for the Deccan lava SAM-018. Figure 7 shows that for $1 \mathrm{GPa}(10 \mathrm{~kb})$ pressure corresponding to about $35 \mathrm{~km}$ depth, olivines of composition $\mathrm{Fo}_{84.6}$ would correspond to an $\mathrm{FeO}(\mathrm{T}) / \mathrm{MgO}$ ratio of 1 , and the $\mathrm{MgO}$ concentration in the primary liquid would be $\sim 11 \%$ (cf. Beane and Hooper, 1988). Yaxley (2000) stated that a hybrid source composition consisting of $\sim 30 \mathrm{wt} \%$ basalt mixed with 70 wt.\% peridotite produces substantially more melt (compared to normal fertile peridotite) during adiabatic ascent in the upper mantle. The melts of such a mixed source are picritic and nepheline-normative at relatively high pressures and low degrees of melting, and become hypersthene-normative picrites or olivine tholeiites at higher degrees of melting and lower pressures. The Deccan tholeiites, such as those of the Western Ghats, may therefore be moderately fractionated daughters of relatively low-MgO olivine tholeiite primary magmas, rather than highly fractionated daughters of picritic liquids.

\section{Trace Element Modelling of the Ambenali Magma Type}

Unlike lavas of some of the lower formations in the Western Ghats, lavas of the Ambenali Formation are

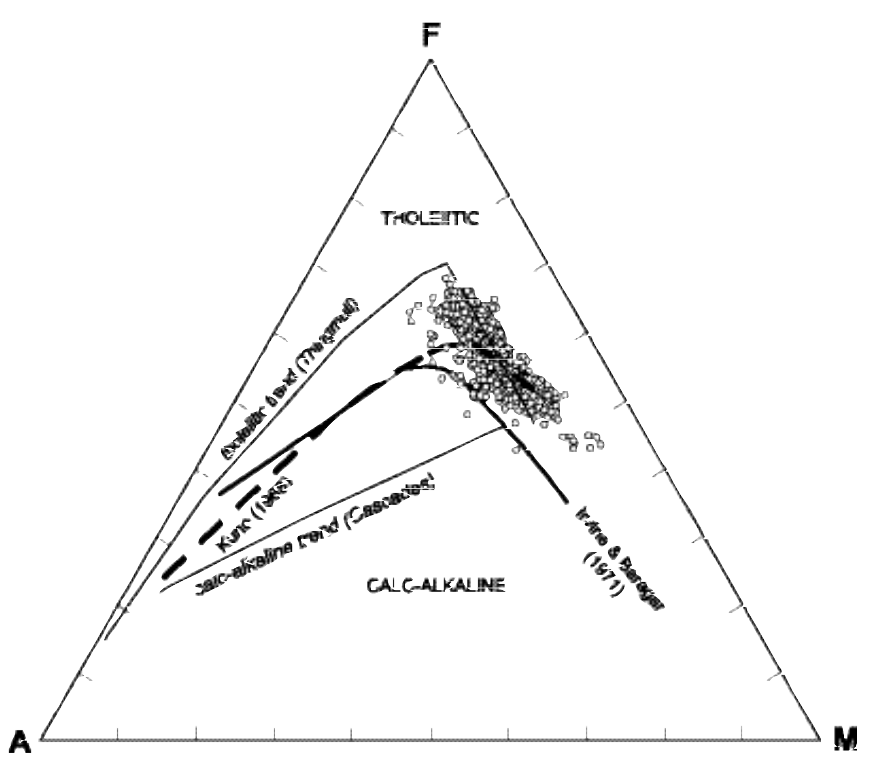

Fig. 6. AFM diagram for Deccan lavas (624 samples, Beane, 1988) of the Western Ghats section. A represents total alkalis, $\mathrm{F}$ is total iron as $\mathrm{FeO}$, and $\mathrm{M}$ is $\mathrm{MgO}$, all calculated on an anhydrous basis. Also shown are the classical calc-alkaline trend of the Cascades (U.S.A.) and tholeiitic trend of Thingmuli Volcano (Iceland). Dividing lines for the tholeiitic and calc-alkaline fields after Kuno (1968) and Irvine and Baragar (1971). 


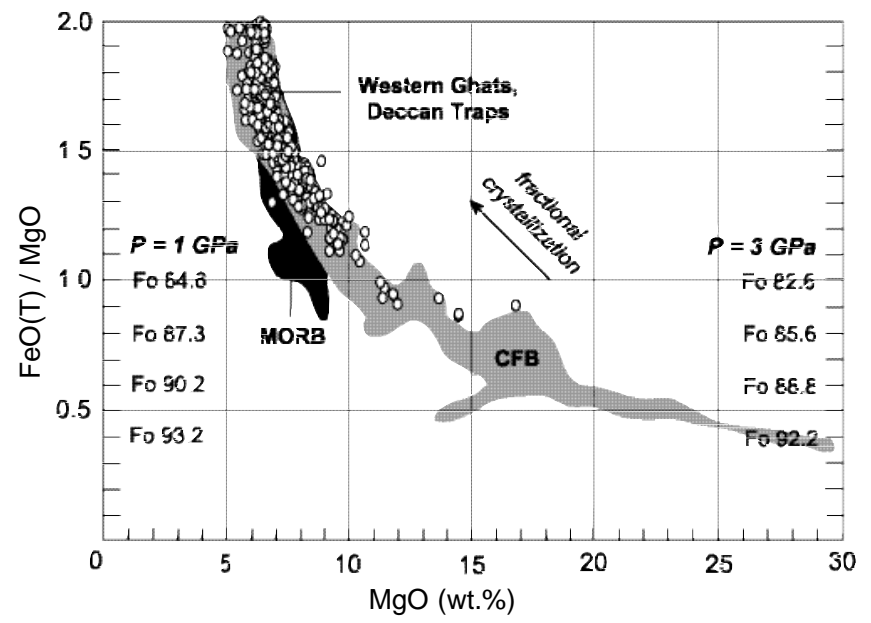

Fig. 7. Plot of $\mathrm{FeO}(\mathrm{T}) / \mathrm{MgO}$ vs. $\mathrm{MgO}$ (wt.\%) for Deccan lavas from the Western Ghats (Beane, 1988). Samples with values of $\mathrm{FeO}(\mathrm{T}) / \mathrm{MgO}$ up to 2.0 only are shown (the highest value is 4.5) to enable easy comparison with MORB and CFB data shown by Yaxley (2000); olivine compositions in equilibrium with primary liquids at $1 \mathrm{GPa}$ and $3 \mathrm{GPa}$ (Yaxley, 2000) are also shown. Notice that $\mathrm{CFB}$, including the Western Ghats lavas, are generally systematically higher in $\mathrm{FeO}(\mathrm{T}) / \mathrm{MgO}$ relative to MORB for the same $\mathrm{MgO}$ value (i.e., same degree of fractionation).

known to be little contaminated by continental lithospheric material. (All Ambenali lavas are by no means uncontaminated, as shown by the range of initial $\varepsilon \mathrm{Nd}$ values from about +7 to +3 ; Fig. 3 ). The Ambenali lavas resemble evolved transitional (T)-MORB in terms of major elements and compatible trace elements; i.e., they are ferrobasalts or "Fe-Ti" basalts with a broadly $\mathrm{T}$ - or enriched (E)-MORB-like incompatible element signature (e.g., Mahoney, 1988). They are taken by many (see Peng and Mahoney, 1995) to represent the composition of the Deccan plume head. Primitive-mantle-normalized patterns of Ambenali lavas show small Nb peaks, and have $\mathrm{Nb}_{\mathrm{N}} / \mathrm{La}_{\mathrm{N}}>1$. Mahabaleshwar lavas have higher $\mathrm{Nb}$ concentrations than the Ambenali, though they have $\mathrm{Nb}_{\mathrm{N}} / \mathrm{La}_{\mathrm{N}}<1$ (Fig. 8a). The Mahabaleshwar component has been variously argued to be old enriched lithospheric mantle or ancient granulitic crust with low ${ }^{206} \mathrm{~Pb} /{ }^{204} \mathrm{~Pb}$ (Fig. 3). The Mahabaleshwar component is thought not to be ocean island mantle, because the lower limit of the Mahabaleshwar Fm. $\left({ }^{206} \mathrm{~Pb} /{ }^{204} \mathrm{~Pb}\right.$ as low as $\left.~ 16.7\right)$ is much lower than observed in modern oceanic lavas (Peng et al., 1994). Could the Ambenali magma type basically be NMORB-type magma contaminated by small amounts of $\mathrm{Nb}$-enriched (possibly phlogopite-bearing) continental lithospheric mantle, as Sheth (1999b) argued? Or, could the Ambenali magma type represent a blend of N-MORB magma with magma derived from ancient recycled crust?

To evaluate further whether the Deccan magmas, particularly the Ambenali magmas, could be blends of magmas derived from peridotite and eclogite, and specifically the model of such eclogite representing ancient oceanic crust, I carried out batch melting calculations on a particular eclogite composition and attempted matching either the batch partial melts themselves, or suitable mixtures of these melts and N-MORB, to the average Ambenali composition. Oceanic crust, after its formation at a ridge, undergoes hydrothermal alteration and lowdegree metamorphism, and during subduction, progressively transforms into amphibolite and eclogite (e.g., Poli, 1993). For the trace element composition of average altered oceanic crust before dewatering, I used the data of Zhang et al. (2004). The mobilities of various elements during dehydration and eclogitization were determined by Kogiso et al. (1997), who used an amphibolite as the starting material. Percent mobility is simply the concentration in starting material minus the concentration in final products, divided by the concentration in starting material (and multiplied by 100). Note that several elements in table 3 have high mobilities exceeding $50 \%$, and the mobility of $\mathrm{Pb}$ is as high as $84.6 \%$. (Mobility of $\mathrm{Y}$ is $-0.5 \%$, which means $\mathrm{Y}$ was enriched in the experimental run products compared to the starting material.) Using these mobility values I calculated the concentrations of these elements in dehydrated, eclogitized oceanic crust (the assumed source material in my calculations). I then calculated batch melts of varying degree (5\% to $90 \%$ ) using the distribution coefficients provided by Klemme et al. (2002), for eclogites having $50: 50,90: 10$, and 10:90 modal proportion of clinopyroxene and garnet.

For the same degree of batch melting, roughly the same concentrations of the various elements in the partial melts were obtained for all three eclogite types. The patterns of batch melts of the eclogite, and their mixtures with $\mathrm{N}-\mathrm{MORB}$, shown in figure 8b, closely mimic the pattern of the source eclogite itself, for all of the highly incompatible elements. In all cases, patterns that come closest to the Ambenali pattern are of a 10\% batch melt, and of a 50:50 bulk mixture of a 5\% batch melt and N-MORB. They are rather similar to the Ambenali in a few characteristics (e.g., normalized $\mathrm{Nb} / \mathrm{La}>1$, a feature of the eclogite itself), but are glaringly different in their $\mathrm{Rb}, \mathrm{U}$ and $\mathrm{Pb}$ values. The patterns of the batch melts and their mixtures, with relatively high $\mathrm{Rb}$ and their $\mathrm{U}$ peaks and large $\mathrm{Pb}$ troughs, contrast strongly with that of the Ambenali which has relatively low $\mathrm{Rb}$, a small trough at $\mathrm{U}$ and no significant trough (or peak) at $\mathrm{Pb}$. It is not clear to what extent the lower $\mathrm{Rb}$ and $\mathrm{U}$ concentrations in the Ambenali can be ascribed to subaerial alteration (this may seem an ad hoc explanation), but it is well-known that altered oceanic crust acquires a much higher $\mathrm{U} / \mathrm{Pb}$ ratio than unaltered oceanic crust, given the high mobility of 
$\mathrm{Pb}$ in seawater (e.g., Kogiso et al., 1997). As regards the $\mathrm{Pb}$ troughs in the batch melts and the mixtures (Fig. 8b), I speculate that the nearly flat Ambenali pattern at $\mathrm{Pb}$ reflects contamination of eclogitized-crust-derived magmas with originally lower $\mathrm{Pb}$ by small amounts of continental lithosphere. Peng et al. (1998) noted that $\mathrm{Pb}$ is highly enriched in most types of continental crust, and the $\mathrm{Pb}$ concentration of a mantle-derived magma may be dramatically affected by small amounts of continental crustal contamination.

In figure $8 \mathrm{~b}$, the pattern for the $5 \%$ batch melt mostly lies above the Ambenali pattern. Increasing the melt fraction shifts the partial melts towards the source eclogite composition. The pattern for the $20 \%$ batch melt is situated below the Ambenali pattern, and therefore, no bulk mixture of the $20 \%$ (or any higher-degree) batch melt with $\mathrm{N}-\mathrm{MORB}$ can reproduce the Ambenali composition. Clearly, if these results are to be believed, the maximum proportion of eclogite in the mantle source of the Deccan Traps is restricted to $\sim 20 \%$. The results are clearly far from spectacular, though several uncertainties and assumptions were involved. For one, the source eclogite is assumed to consist only of clinopyroxene and garnet, but even small amounts of rutile in the eclogite can significantly affect the concentrations of elements such as $\mathrm{Nb}, \mathrm{Ta}$ and $\mathrm{Ti}$ in the partial melts (e.g., Ryerson and Watson, 1987; Klemme et al., 2002). It is also not clear to what extent N-MORB is a suitable mixing end member. Further modelling, desirably with more realistic source compositions (modal, chemical, and also isotopic), seems called for. (A serious handicap is the near-absence of crustal or lithospheric mantle xenoliths, of whatever kind, in the Deccan lavas.) Below I explore other aspects of the model.

\section{Identifying a Recycled Component in the Western Ghats Lavas: the $\Delta \mathrm{Nb}$ Parameter}

$\mathrm{Nb}$ peaks are exhibited by primitive-mantle-normalized multi-element patterns of many ocean island basalts, and depict the recycled oceanic crust component, thought by many to be a mantle plume. The prevailing view is that subducting oceanic crust dehydrates at shallow depths and loses most of its large-ion-lithophile element (LILE) inventory, whereas the high-field-strength elements (HFSE) such as $\mathrm{Ti}$ and $\mathrm{Nb}$ (compatible in a mineral such as rutile) are retained by the slab as it transforms to eclogite and travels to the deep mantle (e.g., Hofmann and White, 1982; Hofmann et al., 1986; McDonough, 1991). Mantle plumes upwelling from the deep mantle are therefore thought to have inherent excess $\mathrm{Nb}$.
Table 3. Data and results of batch melting calculations.

\begin{tabular}{|c|c|c|c|c|c|c|c|c|}
\hline $\begin{array}{c}\text { average } \\
\text { oceanic } \\
\text { crust } \\
\text { (ppm) }\end{array}$ & $\begin{array}{c}\text { element } \\
\text { mobility } \\
(\%)\end{array}$ & $\begin{array}{c}\text { Eclo- } \\
\text { gitized } \\
\text { oceanic } \\
\text { crust } \\
\text { (ppm) } \\
C_{o}\end{array}$ & $\begin{array}{c}\text { bulk } \\
D\end{array}$ & $\begin{array}{l}\text { Ambe- } \\
\text { nali } \\
\text { avg. } \\
\text { (PMN) }\end{array}$ & $\begin{array}{c}\mathrm{N}- \\
\text { MORB } \\
\text { (PMN) }\end{array}$ & $\begin{array}{c}5 \% \\
\text { batch } \\
\text { melt } \\
(\mathrm{ppm}) \\
C_{L}\end{array}$ & $\begin{array}{c}10 \% \\
\text { batch } \\
\text { melt } \\
(\mathrm{ppm}) \\
C_{L}\end{array}$ & $\begin{array}{c}20 \% \\
\text { batch } \\
\text { melt } \\
(\mathrm{ppm}) \\
C_{L}\end{array}$ \\
\hline 12 & 63.0 & 4.44 & 0.002 & 5.20 & 0.88 & 134.72 & 68.68 & 34.68 \\
\hline 26 & 52.5 & 12.35 & 0.0010 & 8.44 & 0.90 & 34.68 & 17.51 & 8.80 \\
\hline 0.27 & & & 0.0 & 11. & & & & 9.84 \\
\hline 0.14 & 29.1 & 0.10 & 0.007 & 10.95 & 2.2 & 84. & 44.80 & 23.16 \\
\hline 2 & 3.6 & 1.93 & 0.01 & 17.50 & 3.27 & 42. & 23.85 & 12.77 \\
\hline 2.50 & 56 & & & 16. & 34 & & & 7.50 \\
\hline 7.50 & & & 0.0 & 14. & 4.2 & 25 & 15.96 & 9.17 \\
\hline 0.20 & 84.6 & 0.03 & 0.1 & 14.00 & 4.23 & 2.13 & 1.76 & 1.30 \\
\hline 110 & 40.8 & 65.1 & 0.043 & 10.14 & 4.27 & 33.96 & 22.24 & 13.16 \\
\hline 7.30 & 30.9 & 5.05 & & 13.74 & 5. & 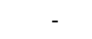 & - & - \\
\hline 74 & $(\approx 0)$ & 74 & 0.24 & 12.59 & 6.61 & 23.77 & 20.91 & 16.85 \\
\hline 2.60 & 13.6 & & 0.23 & 12.88 & 5.92 & 18.87 & 16.51 & 13.20 \\
\hline 28 & -0.5 & 28.14 & 1.7 & 7.82 & 6.15 & 3.71 & 3.79 & 3.96 \\
\hline 3.10 & 1.4 & 3.06 & n.a. & 5.58 & 6.19 & - & - & - \\
\hline
\end{tabular}

Notes: Element concentrations in average altered oceanic crust (in parts per million) are for an undewatered state of the crust (Zhang et al., 2004). Percent mobilities of elements are those calculated by Kogiso et al. (1997) for subducted, dehydrated, eclogitized oceanic crust. Although they did not measure $\mathrm{Zr}$, the mobility of $\mathrm{Zr}$ is here assumed to be zero since $\mathrm{Zr}$ (like $\mathrm{Nb}$ ) is a very alteration-resistant element. Bulk $D$ (distribution coefficient) values for the elements are for the case of partial melting of eclogite containing 50\% modal clinopyroxene and $50 \%$ modal garnet (Klemme et al., 2002). n.a. means value not available. PMN means value normalized by concentration in primitive mantle; primitive mantle normalizing values and N-MORB values are from Sun and McDonough (1989). The batch melting equation (Shaw, 1970) is $C_{L}=C_{o} /[D(1-F)+F]$, where $C_{o}$ is the concentration in original (source) rock, $C_{L}$ the concentration in liquid (partial melt), $D$ is the bulk distribution coefficient, and $F$ is the melt fraction with values between 0 and 1 . Note that the $C_{L}$ values tabulated are actual concentrations in ppm.

There are two caveats to using the high $\mathrm{Nb}$ concentrations observed in many ocean island basalts to infer a source enriched in $\mathrm{Nb}$. One is provided by the study of Ionov and Hofmann (1995) of mantle xenoliths from Central Asia. Ionov and Hofmann (1995) argued that, during subduction and dehydration of a slab, $\mathrm{Nb}$ is not retained by the slab but is given off like the LILE, and is concentrated in hydrous minerals like phlogopite which crystallize in the mantle wedge under open system conditions. If this phlogopite-bearing mantle is melted later on and the phlogopite consumed in melting, the magma produced would have a high $\mathrm{Nb}$ content (Sheth, 1999b). Workers subsequent to Ionov and Hofmann (1995), however, have argued that $\mathrm{Nb}$ is largely immobile during slab dehydration (e.g., Kogiso et al., 1997). The other caveat is that $\mathrm{Nb}$ is a highly incompatible element in the anhydrous peridotite assemblage and would be strongly enriched in its initial low-degree partial melts (Sun and McDonough, 1989; Baksi, 2001).

Both these caveats (phlogopite-bearing mantle source and low-degree melting) do not hold for the voluminous 
Deccan flood basalts that are almost entirely subalkalic and therefore not low- $F$ melts. These caveats also do not hold for Icelandic tholeiites and normal mid-ocean ridge basalts (N-MORB). Fitton et al. (1997) showed that Icelandic basalts and normal mid-ocean ridge basalts (N-MORB) define parallel tight arrays on a plot of $\log (\mathrm{Nb} / \mathrm{Y})$ vs. $\log (\mathrm{Zr} / \mathrm{Y})$, with $\mathrm{N}-\mathrm{MORB}$ relatively poor in $\mathrm{Nb}$ (Fig. 9). The upper and lower bounds of the Icelandic basalt array are given by the following equations respectively:

$$
\log (\mathrm{Nb} / \mathrm{Y})=1.92 \log (\mathrm{Zr} / \mathrm{Y})-1.176
$$$$
\log (\mathrm{Nb} / \mathrm{Y})=1.92 \log (\mathrm{Zr} / \mathrm{Y})-1.740
$$

Fitton et al. (1997) defined a parameter $\Delta \mathrm{Nb}$ based on this diagram as follows:

$$
\Delta \mathrm{Nb}=1.74+\log (\mathrm{Nb} / \mathrm{Y})-1.92 \log (\mathrm{Zr} / \mathrm{Y})
$$

$\Delta \mathrm{Nb}$ is a fundamental source characteristic and is insensitive to the effects of variable degrees of partial melting, source depletion through melt removal, and subsequent alteration. $\mathrm{N}-\mathrm{MORB}$ have negative $\Delta \mathrm{Nb}$ values and Icelandic basalts have positive $\Delta \mathrm{Nb}$ values. Contamination of N-MORB magmas with continental crust can also never produce positive $\Delta \mathrm{Nb}$ values in the contaminated melts, because both N-MORB and the continental crust are depleted in $\mathrm{Nb}$ relative to other
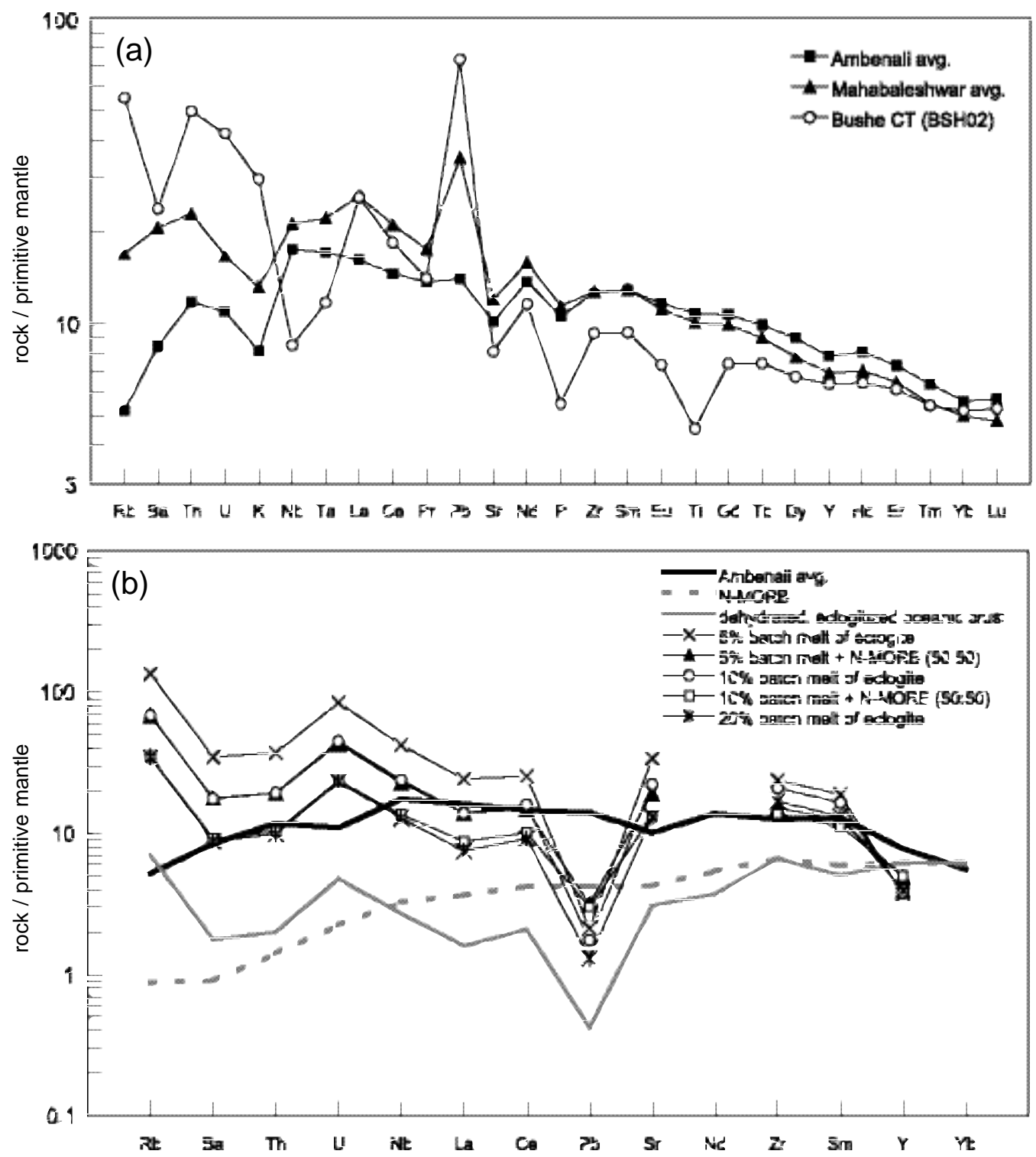

Fig. 8. (a) Primitive-mantle-normalized (values from Sun and McDonough, 1989) multi-element patterns for average Ambenali and Mahabaleshwar Formation lavas and the Bushe Chemical Type (sample BSH02 of Beane, 1988). The pronounced Nb-Ta troughs of the Bushe pattern are a result of crustal contamination (e.g., Mahoney, 1988). (b) Comparison of primitive-mantle-normalized multi-element patterns for the Ambenali magma type, N-MORB, eclogitized oceanic crust, and its various batch melts and their mixtures with N-MORB. 
incompatible elements (e.g., both have primitive-mantlenormalized $\mathrm{Nb} / \mathrm{La}<1$ ) and the continental crust has a $\Delta \mathrm{Nb}$ value equal to zero or slightly negative. The $\Delta \mathrm{Nb}$ value for an individual basalt sample shows the excess or deficiency in $\mathrm{Nb}$ of the mantle source of that basalt relative to the lower bound of the Iceland array. Positive values of $\Delta \mathrm{Nb}$ imply an Icelandic mantle source and negative values a depleted upper mantle source. Samples with $\Delta \mathrm{Nb}=-1$ and +1 have respectively one-tenth and ten times the $\mathrm{Nb}$ contents of samples with the same $\mathrm{Zr} / \mathrm{Y}$ falling on the $\Delta \mathrm{Nb}=0$ reference line. Baksi (2001), on the basis of this diagram, argued for deep-mantle plume components in many continental and oceanic flood basalts and ocean island lavas. However, inherent excess $\mathrm{Nb}$ in a mantle source, though it may indicate recycled oceanic crust, still provides no depth constraints. A shallowly recycled (upper mantle) eclogitic slab, or a slab of ancient eclogite residing within the continental lithosphere, would satisfy the observations equally well. I therefore take positive $\Delta \mathrm{Nb}$ values of lavas (and thereby mantle sources) as simply a signature of $\mathrm{Nb}$-enriched, eclogitized oceanic crust, not a deep plume.

Continental basalts may be significantly contaminated by continental crust, and depending on the degree and type of contamination and the nature of the contaminant, they can have their $\Delta \mathrm{Nb}$ values lowered variably. Figure 9 shows the positions of the Deccan basalts of the Western Ghats on the $\log (\mathrm{Nb} / \mathrm{Y})$ vs. $\log (\mathrm{Zr} / \mathrm{Y})$ diagram. I have combined the basalts of Jawhar to Poladpur formations to avoid cluttering, but plotted the Ambenali and Mahabaleshwar Formation basalts separately, the reason for which will be immediately clear. The Jawhar to Poladpur Fm. basalts considered together (Fig. 9), or when plotted individually (not shown), straddle the $\Delta \mathrm{Nb}=0$ boundary line. Significant crustal contamination has occurred in the petrogenetic evolution of many Jawhar to Poladpur Fm. basalts (e.g., Beane et al., 1986; Peng et al., 1994), and can be told from many criteria, one of them $\mathrm{Sr}$ isotopic ratios (Table 1). Therefore the positions of many samples below the $\Delta \mathrm{Nb}=0$ line is not surprising. On the other hand, the aphyric basalt SAM-018 from the Thakurvadi Formation, for which I considered an eclogitebearing mantle source possible, has a $\Delta \mathrm{Nb}$ value of +0.07 . (Unfortunately, isotopic data are not yet available for this sample.)

The remarkable feature in figure 9 is that nearly all Ambenali and all Mahabaleshwar Fm. basalts plot right within the bounds of the Icelandic array. Very few (2 of 52) Ambenali samples have negative $\Delta \mathrm{Nb}$ values and the rest have positive values, and all Mahabaleshwar samples (13) have positive $\Delta \mathrm{Nb}$ values (Fig. 10). These can be ascribed neither to unusual (e.g., phlogopite-rich) mantle sources nor to low- $F$ melting, as both Ambenali and Mahabaleshwar Formations are wholly made up of subalkalic tholeiites, and are in fact two of the thickest formations of the Western Ghats (Table 1). Also, the positive $\Delta \mathrm{Nb}$ values of all Mahabaleshwar lavas mean that if they were contaminated by granulitic crust, as suggested by their ${ }^{206} \mathrm{~Pb} /{ }^{204} \mathrm{~Pb}$ ratios, this contamination was insufficient to bring down their $\Delta \mathrm{Nb}$ to zero or negative values, and the $\Delta \mathrm{Nb}$ values of the magmas before contamination would have been even more strongly positive. Alternatively, it is possible that the contaminant granulite itself did not have a strongly negative $\Delta \mathrm{Nb}$ value. A simple interpretation of the observations is that the Ambenali and Mahabaleshwar Formations have a recycled oceanic crust component in them. A relatively fusible eclogite (or pyroxenite) component, of the type postulated in this paper, can explain well the large volumes of these lavas.

\section{The Volume of Eclogite and Eclogite- generated Melt}

The continental lithosphere was already at least 150-200 km- thick well in the Archaean as evidenced by Archaean diamonds (e.g., Boyd et al., 1985). Accreting protocontinental nuclei of India may easily have been $150 \mathrm{~km}$ thick, and could hold a slab of oceanic crust that, if in a steeply inclined or vertical position, could be at least this high (cf. Foulger et al., 2005). The average thickness of the modern oceanic crust is $7 \pm 1 \mathrm{~km}$ (e.g., White et al., 1992), of which the basaltic part (pillow basalts and sheeted dykes) makes up $\sim 2 \mathrm{~km}$ (Boudier and Nicolas, 1985; Nicolas, 1989). Archaean oceanic crust may have been significantly thicker, warmer and more

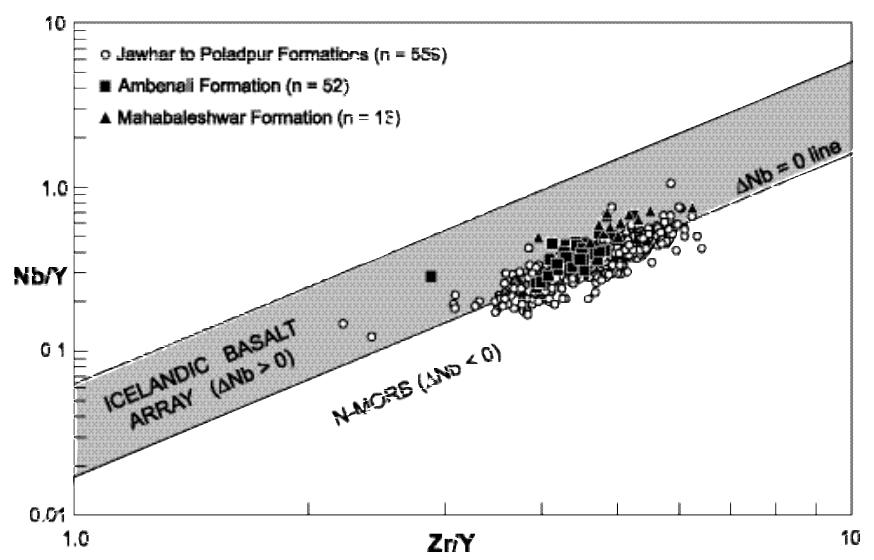

Fig. 9. The Western Ghats lavas, Deccan Traps (Beane, 1988) on the $\log (\mathrm{Nb} / \mathrm{Y})$ vs. $\log (\mathrm{Zr} / \mathrm{Y})$ diagram of Fitton et al. (1997). The Icelandic basalt array is also shown. Samples plotting above the $\Delta \mathrm{Nb}=0$ line (lower bound of the Iceland array) are thought to have a recycled oceanic crust component. 


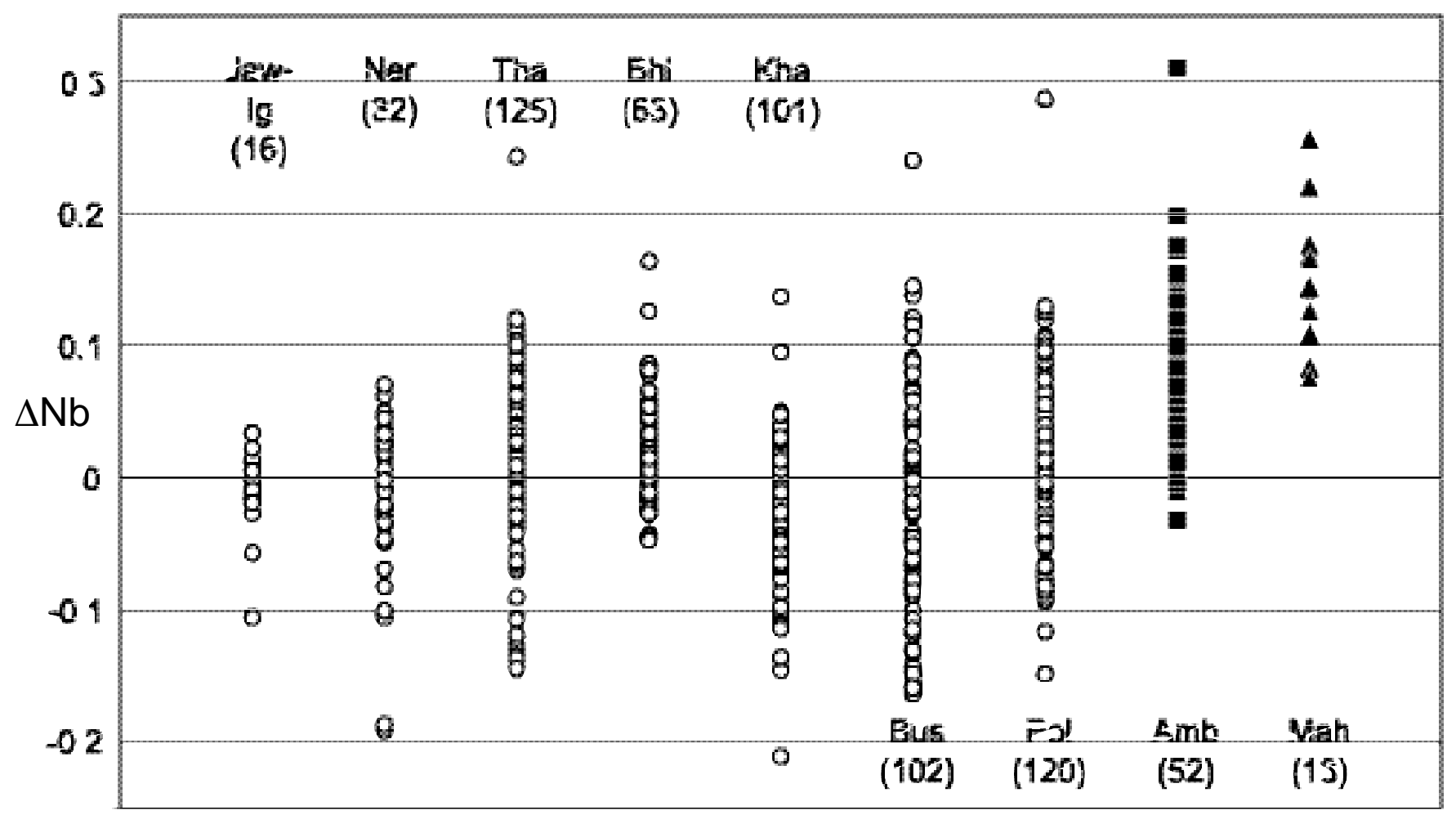

Fig. 10. Range of $\Delta \mathrm{Nb}$ values calculated for lavas of the various Western Ghats formations, using the formula of Fitton et al. (1997) and the data of Beane (1988).

buoyant owing to a hotter Archaean mantle (e.g., Bickle, 1978; Campbell and Jarvis, 1984; Hamilton, 1998 and references therein). A thickness of $5 \mathrm{~km}$ is considered here a reasonable assumption for a flat, vertical slab, but this thickness would be effectively larger if the slab were imbricated (Foulger et al., 2005).

Assuming that a vertical or near-vertical, $150 \mathrm{~km}$-deep, $5 \mathrm{~km}$-thick basaltic layer in an ancient suture zone (such as the Narmada zone) melted over a length of $500 \mathrm{~km}$ of the suture zone, and that total melting was achieved, the magma volume produced would be $0.375 \times 10^{6} \mathrm{~km}^{3}$. Assuming an additional such slab along the western Indian continental margin and its total melting, the total volume obtained is $0.75 \times 10^{6} \mathrm{~km}^{3}$. This is half the estimated original volume of the Deccan $\left(1.5 \times 10^{6} \mathrm{~km}^{3}\right)$, assuming an original area for Deccan of $1.5 \times 10^{6} \mathrm{~km}^{2}$ (Wadia, 1975) and a reasonable original average thickess of $1 \mathrm{~km}$ over this entire area. Thus half the volume of the Deccan would have come from eclogite alone. The assumption of total melting of the eclogite may be unrealistic, though the considerably lower solidus and liquidus of eclogite compared to peridotite mean that heat conduction out of the ambient peridotite into the eclogite should be effective in melting it to high melt fractions. Even if it were assumed that the eclogite melts to $50 \%$, one-fourth the total volume of the Deccan lavas would come from it. Note that although eclogite and basalt have the same chemical composition, it is not necessary to achieve total melting of eclogite to produce a liquid of basaltic composition, as each melt fraction yields in general a basaltic composition (Yoder, 1976), excepting the near-solidus eclogite partial melts that are highly siliceous (rhyodacite or dacite, Yaxley and Green, 1998).

It is assumed that all magma formed was erupted, i.e., no magma was trapped in dykes, magma chambers, etc. This assumption is more or less valid, because the density factor is less serious for such magmas than for picritic liquids. Picritic liquids, due to their high density, must pond at subcrustal or midcrustal depths to crystallize and fractionate olivine, and only then can they rise upward through the effective density filter that is the continental crust (Stolper and Walker, 1980). If one-fourth the total erupted volume of the Deccan lavas (a conservative estimate) came from eclogite alone, this volume is quite considerable.

\section{A Physical Model for Melting the Eclogite}

Although eclogite-rich plumes have been proposed (e.g., Cordery et al., 1997; Takahashi et al., 1998), an important problem is that adding large amounts of eclogite to a peridotitic plume creates negative buoyancy in the 
plume, given the higher density $\left(3.4-3.5 \mathrm{gm} / \mathrm{cm}^{3}\right.$; Ito and Kennedy, 1971) of eclogite than of peridotite $\left(3.3 \mathrm{~g} / \mathrm{cm}^{3}\right)$. Thus eclogite-rich plumes cannot upwell (O'Hara et al., 2003). Plume proponents have tried to circumvent this problem by proposing appropriately higher temperatures (greater thermal buoyancy) for plumes (e.g., Cordery et al., 1997), but such plumes should encounter their solidus at great depth and will still not be able to upwell (O'Hara et al., 2003). Therefore, if substantial amounts of eclogite exist within peridotite, the tendency of the mass would be to $\operatorname{sink}$, not upwell.

I propose delamination of eclogite to avoid the paradox of upwelling, dense eclogite-rich plumes. Delamination means the removal of the lower lithosphere and its incorporation into the asthenosphere. Delamination causes lithospheric thinning, so that ambient mantle can convectively flow toward the thin lithosphere (e.g., Czamanske et al., 1998), upwell into the gap, undergo decompression, and melt. The delaminated lithosphere can itself melt (e.g., Smith, 1993). Elkins-Tanton (2005) mentions two necessary conditions for delamination to occur: (1) The lower lithosphere becomes gravitationally unstable, i.e., is denser than the material underlying it, and (2) The viscosity of the lower lithosphere is reduced sufficiently for it to flow downward under the influence of gravity (Elkins-Tanton et al., 2002). Numerical modelling work (Elkins-Tanton, 2005) suggests that, over a range of lithospheric thicknesses and mantle potential temperatures, these processes can create a wide range of melt volumes, even up to the size of a flood basalt province, and that delamination is a viable process for the Siberian flood basalts.

I suggest that the onset of crustal extension and lithospheric rifting along India's ancient sutures, well before the flood basalt phase in the Deccan Traps (see Sheth, 1999a, 2000), led to the realization of both the required conditions mentioned above (Fig. 11). In this model, as the lithosphere begins to rift along the ancient suture, the eclogite trapped along the suture becomes suspended in the mantle, and begins to sink bodily. As it sinks, ambient asthenospheric peridotitic mantle flows into the gap created, depressurizes adiabatically, and melts. If the eclogite is originally hydrated, it begins to dehydrate as it heats up, and the water released into the surrounding upwelling peridotite causes further melting of it. Melting of the eclogite will ensue when it is sufficiently heated, and melts of eclogite will blend with melts of peridotite to yield Fe-rich primary magmas.

Yasuda et al. (1997), who proposed a composite (eclogite-peridotite) upwelling plume model, made the important point that eclogite melts extensively before the peridotite begins to melt, but the melts cannot escape the source region until peridotite melting allows large-scale melt connectivity, at which point large volumes of melt may be released cataclysmically. They also showed that the major element compositions of hybrid magmas derived by melting of such mixed mantle sources is comparable to that of CFBs, and argued that some CFBs could be nearprimary magmas.

Notably, the model of Yasuda et al. (1997) involved upwelling, not sinking, eclogite. How about the sinking eclogite in the model proposed here? One can notice that dehydration and partial melting of such sinking eclogite should make it cooler and harder to melt further. I note, however, that the residual eclogite would be considerably lighter compared to the original unmelted rock, and at this point it would be entrained into the mass upwelling of asthenospheric peridotite. As both rise, the residual eclogite will become a heat sink - it will draw heat diffusively from the surrounding peridotite, heat up, and because of the heating and continuous decompression, will melt much more on ascent (Fig. 12). The idea is based on the work of Hirschmann and Stolper (1996) who, based on many major and trace element and isotopic grounds, argued for the presence of garnet pyroxenite in the source of MORB. Pyroxenite, like eclogite, is a relatively fusible mantle rock, and pyroxenite in the sub-lithospheric mantle may represent subducted basaltic crust. An upwelling mixture of pyroxenite and host peridotite (Fig. 12) has much greater melt productivity over the same depth interval than pure peridotite, because of the low-melting pyroxenite component in the mixture. Such a mixture can also have much greater melt productivity than upwelling pyroxenite, the reason being diffusion of heat out of the host peridotite and into the enclosed pyroxenite. As worked out by Sleep (1984), such thermal diffusion is efficient and rapid as long as the mantle heterogeneity that is being heated does not exceed a few kilometres in size. It would appear that the results of Hirschmann and Stolper (1996) would also apply equally well to eclogite, and the thermal requirements for melting a substantial mass of eclogite in my model would be met with.

\section{Discussion and Conclusions}

As for Iceland, a Fe-rich mantle source has been proposed for the Columbia River CFB of western U.S.A. (Wright et al., 1988; Takahashi et al., 1998) and argued to represent ancient oceanic crust subducted and recycled via a deep mantle plume (Takahashi et al., 1998). It is pertinent that this $\mathrm{CFB}$, the only post-Precambrian CFB in North America, is situated on a tectonic boundary adjacent to the only craton in North America, the Wyoming Craton (Anderson et al., 1992). A more appropriate model 
ANCIENT
SUTURE

\begin{tabular}{|l|l|l|}
\hline lithosphere & & \\
\hline asthenosphere & eclogite & \\
\hline
\end{tabular}

(b) MODEFN

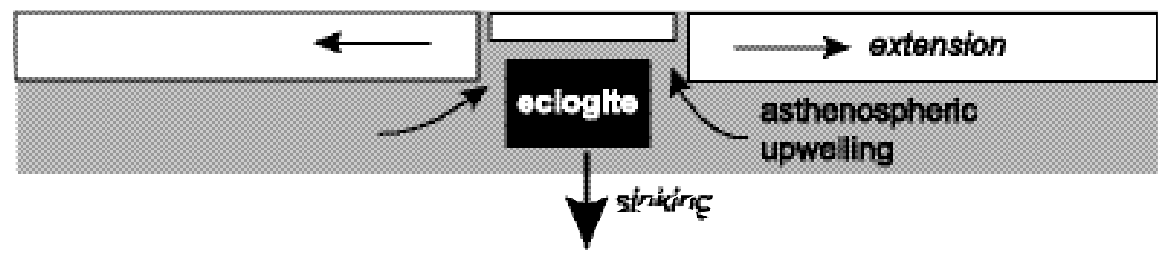

(c)

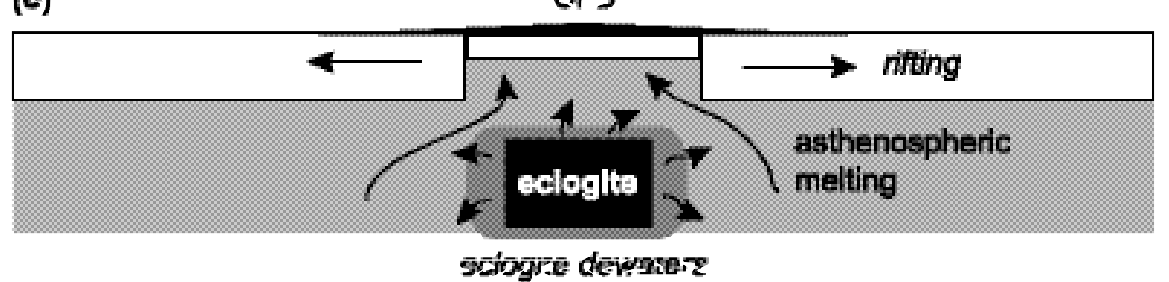

sind imatts

(d)

progressivaly thinred

growirg CFa pile / linosghere in nif zone

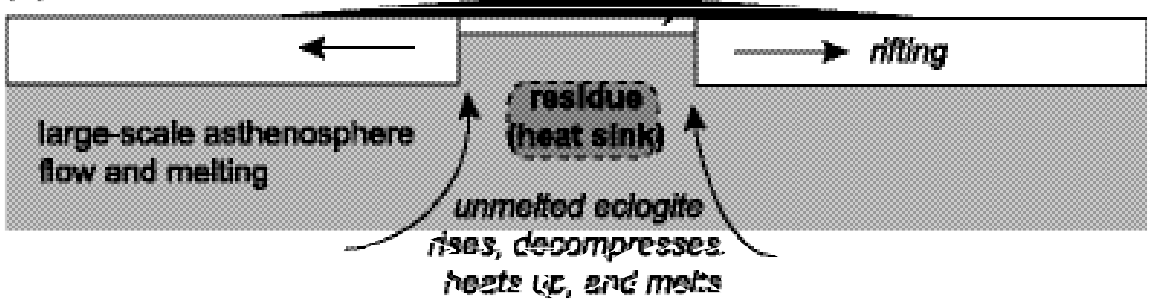

Fig. 11. Schematic model (not to scale) to illustrate the proposed mechanism of delamination of eclogite. (a) Eclogite exists stably along an old suture zone. (b) Lithospheric extension and rifting begin, and the eclogite delaminates and sinks. Surrounding asthenospheric mantle flows into the gap, decompresses and melts. (c) Continued sinking of eclogite leads to its dehydration and melting, while the water released by the eclogite promotes melting in the asthenospheric mantle above. Modified after Elkins-Tanton (2004). (d) The residue of partial melting of eclogite gets entrained into the mass flow of asthenosphere and ascends; as it ascends it decompresses, heats up due to thermal diffusion out of the host peridotite, and melts much more.

for this CFB may be that of Smith (1992), involving backarc convection and pyroxenite melting. In fact, Smith (1993) showed a close correlation between the locations of CFB provinces, hotspot tracks, and ancient sutures. He even noted the association of the Deccan and Rajmahal Traps with sutures in India and emphasized the contributions to ocean island volcanism from enriched mantle delaminated from under sutures.

The garnet peridotite or pyrolite plume model, which has long been popular in models of large-volume basaltic magmatism, ascribes excess magmatism to higher-thanaverage temperatures. More recent models of petrogenesis emphasize the petrological diversity of the mantle and include important roles for eclogite or pyroxenite, besides volatiles (especially $\mathrm{CO}_{2}$ ) (e.g., Presnall et al., 2002; Foulger et al., 2005), and do not require high absolute temperatures. Gibson et al. (2000) and Gibson (2002) consider that several CFBs probably had Fe-rich (eclogitebearing) mantle sources but, believing that CFBs are derived from mantle plume heads, they propose that the required eclogite represents deeply recycled oceanic crust entrained within uprising plumes. The observations are then explained by invoking "plume head heterogeneity", but structural and petrological complexities of the continents have generally remained neglected in the plume model. The plume model, focussed as it is on the deep mantle, assumes no continents, no geology, no fracture zones, no lateral temperature variations in the 


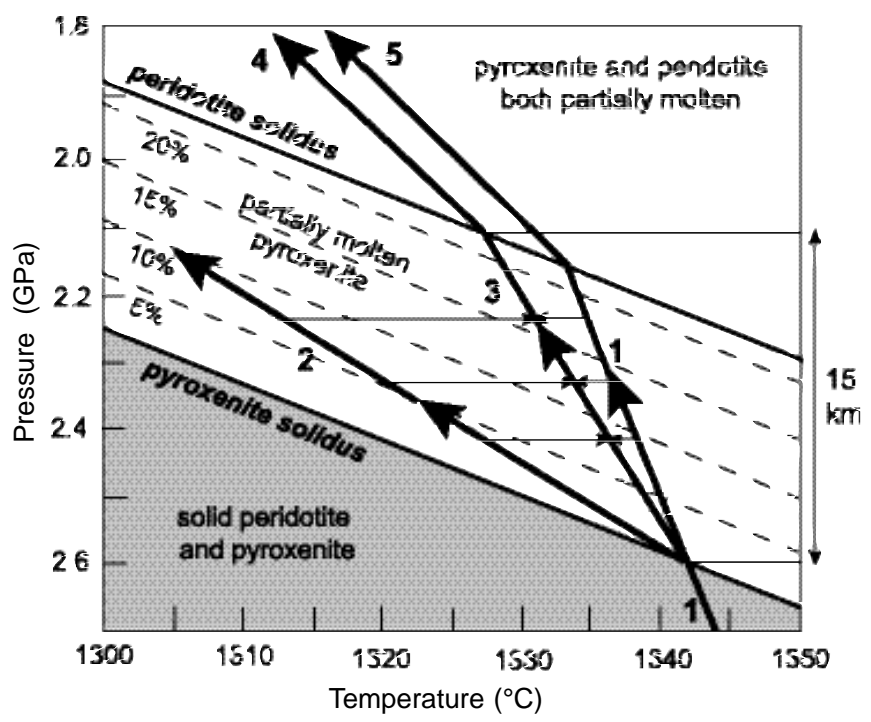

Fig. 12. Schematic diagram, slightly modified from Hirschmann and Stolper (1996), showing thermal equilibration between pyroxenite and host peridotite in upwelling mantle. Heavy lines with arrowheads show the paths of upwelling mantle. 1 is an adiabat for an upwelling mass of pyroxenite-bearing peridotite. When it intersects the pyroxenite solidus, the pyroxenite begins melting but the host peridotite remains solid. The latent heat of melting cools the residual pyroxenite (trajectory 2, gentler than 1) unless cooling is compensated by thermal diffusion out of the peridotite. The dashed lines are isopleths of constant melt fraction in the pyroxenite. If the peridotite loses no heat, it continues to upwell along the adiabat 1 until it touches its own solidus and begins melting. It will now follow trajectory 5. If, however, thermal diffusion out of the peridotite into the pyroxenite is efficient, both will thermally equilibrate (along the small horizontal converging arrows) and the upwelling mass made up of both, with the same temperature throughout, will follow the curve marked 3. After intersecting the peridotite solidus, the mass will follow curve 4. If instead of pyroxenite the upwelling peridotite contained eclogite, qualitatively the same effects should be observed.

mantle (so no mantle convection), and no internal heating (Anderson, 1996).

The model I have proposed here, of an excess basaltic component in the source of the Deccan flood basalts, and its derivation from ancient oceanic crust preserved within the Indian continental lithosphere, is based on the possible Fe-rich mantle sources for the voluminous Deccan basalts, and first-order structural-tectonic features of the Indian subcontinent. It is worth exploring in detail. I conclude, as I have done previously based on many types of data (Sheth, 1999a, b, 2000, 2005), that CFB events like the Deccan do not require, and are not consistent with, the deep mantle plume model. The original plume model has ascribed CFBs such as the Deccan to high mantle temperatures alone. Important roles for mantle with extra fertility or volatile content are now increasingly recognized, but recent plume models simply assume plumes to have these required attributes (e.g., Cordery et al., 1997; Baker et al., 1998; Gibson et al., 2000; Gibson, 2002). The key point is, when volatiles are considered, easily fusible and fertile mantle invoked, and continental geology paid due attention, one may no longer need deep mantle plumes.

\section{Acknowledgments}

I am highly indebted to John Mahoney for providing the Deccan data used in this paper, and for an unusually detailed, highly critical and very helpful official review, along with valuable advice. I also thank M. Santosh for his editorial handling and patience. Alan Smith, Gillian Foulger, Don Anderson and Dean Presnall have made many valuable comments on earlier versions of the paper. This work was supported in part by research grant \#03IR014 from the Industrial Research and Consultancy Centre (IRCC), IIT Bombay.

\section{References}

Allègre, C.J. and Turcotte, D. (1986) Implications of a two component marble-cake mantle. Nature, v. 323, pp. 123-127.

Anderson, D.L. (1996) Enriched asthenosphere and depleted plumes. Int. Geol. Rev., v. 38, pp. 1-21.

Anderson, D.L., Zhang, Y.-S. and Tanimoto T (1992) Plume heads, continental lithosphere, flood basalts and tomography. In: Storey, B.C., Alabaster, T. and Pankhurst, R.J. (Eds.), Magmatism and the causes of continental break-up. Geol. Soc. London Spec. Pub. No. 68, pp. 99-124.

Anil Kumar, Pande, K., Venkatesan, T.R. and Bhaskar Rao, Y.J. (2001) The Karnataka Late Cretaceous dykes as products of the Marion hotspot at the Madagascar-India breakup event: evidence from ${ }^{40} \mathrm{Ar}^{39} \mathrm{Ar}$ geochronology and geochemistry. Geophys. Res. Lett., v. 28, pp. 2715-2718.

Baker, J., Chazot, G., Menzies, M. and Thirlwall, M. (1998) Metasomatism of the shallow mantle beneath Yemen by the Afar plume -implications for mantle plumes, flood volcanism, and intraplate volcanism. Geology, v. 26, pp. 431-434.

Baksi, A.K. (2001) Search for a deep-mantle component in mafic lavas using a Nb-Y-Zr plot. Can. J. Earth Sci., v. 38, pp. 813-824.

Basaltic Volcanism Study Project (1981) Basaltic volcanism on the terrestrial planets. Pergamon Press, New York, 1286p.

Beane, J.E. (1988) Flow stratigraphy, chemical variation and petrogenesis of Deccan flood basalts from the Western Ghats, India. Ph.D. Diss., Washington State Univ., Pullman.

Beane, J.E. and Hooper, P.R. (1988) A note on the picrite basalts of the Western Ghats, Deccan Traps, India. In: Subbarao, K.V. (Ed.), Deccan flood basalts. Geol. Soc. India Mem. No. 10, pp. 117-134.

Beane, J.E., Turner, C.A., Hooper, P.R., Subbarao, K.V. and Walsh, J.N. (1986) Stratigraphy, composition and form of the Deccan basalts, Western Ghats, India. Bull. Volcanol., v. 48, pp. 61-83.

Bickle, M.J. (1978) Heat loss from the Earth: a constraint on Archaean tectonics from the relation between geothermal gradients and the rate of plate production. Earth Planet. 
Sci. Lett., v. 40, pp. 301-315.

Biswas, S.K. (1987) Regional tectonic framework, structure and evolution of the western marginal basins of India. Tectonophys., v. 135, p. 307-327.

Boudier, F. and Nicolas, A. (1985) Harburgite and lherzolite subtypes in ophiolitic and oceanic environments. Earth Planet. Sci. Lett., v. 76, pp. 84-92.

Boyd, F.R., Gurney, J.J. and Richardson, S.H. (1985) Evidence for a 150-200-km thick Archean lithosphere from diamond inclusion thermobarometry. Nature, v. 315, p. 387-409.

Burke, K.C. (1996) The African plate. S. Afri. J. Geol., v. 99, pp. 341-409.

Campbell, I.H. and Griffiths, R.W. (1990) Implications of mantle plume structure for the evolution of flood basalts. Earth. Planet. Sci. Lett., v. 99, pp. 79-93.

Campbell, I.H. and Jarvis, G.T. (1984) Mantle convection and early crustal evolution. Precambrian Res., v. 26, pp. 15-56.

Chauvel, C. and Hemond, C. (1999) Melting of a complete section of recycled oceanic crust: trace element and $\mathrm{Pb}$ isotopic evidence from Iceland. Geochem. Geophys. Geosyst., v. 1, 1999GC000002.

Cordery, M.J., Davies, G.F. and Campbell, I.H. (1997) Genesis of flood basalts from eclogite-bearing mantle plumes. J. Geophys. Res., v. 102, pp. 20179-20197.

Cox, K.G. (1980) A model for flood basalt vulcanism. J. Petrol., v. 21, pp. 629-650.

Cox, K.G. (1999) The picrite basalt controversy. In: Subbarao, K.V. (Ed.), Deccan volcanic province, pp. xxxi-xxxx. Geol. Soc. India Mem. No. 43(1).

Cox, K.G. and Mitchell, C. (1988) Importance of crystal settling in the differentiation of Deccan Trap basaltic magmas. Nature, v. 333, pp. 447-449.

Czamanske, G.K., Gurevitch, A.B., Fedorenko, V. and Simonov, O. (1998) Demise of the Siberian plume: palaeogeographic and palaeotectonic reconstruction from the prevolcanic and volcanic record, North-Central Siberia. Int. Geol. Rev., v. 40, pp. 95-115.

Dziewonski, A.M. (2003) Global seismic tomography: what we can really say and what we make up. Abst. in The Hotspot Handbook, Proc. Penrose Conf. Plume IV: Beyond the plume hypothesis, Hveragerdi, Iceland, August 2003.

Dziewonski, A.M. (2005) The robust aspects of global seismic tomography. In: Foulger, G.R., Natland, J.H., Presnall, D.C. and Anderson, D.L. (Eds.), Plates, plumes and paradigms. Geol. Soc. Amer. Spec. Paper, (in press).

Elkins-Tanton, L.T. (2005) Continental magmatism caused by lithospheric delamination. In: Foulger, G.R., Natland, J.H., Presnall, D.C. and Anderson, D.L. (Eds.), Plates, plumes and paradigms. Geol. Soc. Amer. Spec. Paper, revision.

Elkins-Tanton, L.T., Van Orman, J.A., Hager, B.H. and Grove, T.L. (2002) Reexamination of the lunar magma ocean cumulate overturn hypothesis: melting or mixing is required. Earth Planet. Sci. Lett., v. 196, pp. 249-259.

Fitton, J.G., Saunders, A.D., Norry, M.J., Hardarson, B.S. and Taylor, R.N. (1997) Thermal and chemical structure of the Iceland plume. Earth Planet. Sci. Lett., v. 153, pp. 197-208.

Foulger, G.R. and Anderson, D.L. (2005) A cool model for the Iceland hotspot. J. Volcanol. Geotherm. Res., (in press).

Foulger, G.R., Natland, J.H. and Anderson, D.L. (2005) A source for Icelandic magmas in remelted Iapetus crust. J. Volcanol. Geotherm. Res., (in press).
Foulger, G.R., Pritchard, M.J., Julian, B.R., Evans, J.R., Allen, R.M., Nolet, G., Morgan, W.J., Bergsson, B.H., Erlendsson, P., Jakobsdóttir, S., Ragnarsson, S., Stefansson, R. and Vogfjörd, K. (2000) The seismic anomaly beneath Iceland extends down to the mantle transition zone and no deeper. Geophys. J. Int., v. 142, pp. F1-F5.

Foulger, G.R., Pritchard, M.J., Julian, B.R., Evans, J.R., Allen, R.M., Nolet, G., Morgan, W.J., Bergsson, B.H., Erlendsson, P., Jakobsdóttir, S., Ragnarsson, S., Stefansson, R. and Vogfjörd, K. (2001) Seismic tomography shows that upwelling beneath Iceland is confined to the upper mantle. Geophys. J. Int., v. 146, pp. 504-530.

Gaetani, G.A. and Grove, T.L. (1998) The influence of water on melting of mantle peridotite. Contrib. Mineral. Petrol., v. 131, pp. 323-346.

Gibson, S.A. (2002) Major element heterogeneity in Archean to Recent mantle plume starting-heads. Earth Planet. Sci. Lett., v. 195, pp. 59-74.

Gibson, S.A., Thompson, R.N. and Dickin, A.P. (2000) Ferropicrites: geochemical evidence for Fe-rich streaks in upwelling mantle plumes. Earth Planet. Sci. Lett., v. 174, pp. 355-374.

Green, D.H. (1973) Experimental melting studies on a model upper mantle composition of high pressure under $\mathrm{H}_{2} \mathrm{O}$ saturarated and $\mathrm{H}_{2} \mathrm{O}$-unsaturated conditions. Earth Planet. Sci. Lett., v. 19, pp. 37-45.

Hamilton, W. (1998) Archaean magmatism and deformation were not products of plate tectonics. Precambrian Res., v. 91, pp. 143-179.

Hirose, K. and Kawamoto, T. (1995) Hydrous partial melting of lherzolite at $1 \mathrm{GPa}$ : the effect of $\mathrm{H}_{2} \mathrm{O}$ on the genesis of basaltic magmas. Earth Planet. Sci. Lett., v. 133, pp. 463-473.

Hirschmann, M.M. and Stolper, E.M. (1996) A possible role for garnet pyroxenite in the origin of the "garnet signature" in MORB. Contrib. Mineral. Petrol., v. 124, pp. 185-208.

Hofmann, A.W. and White, W.M. (1982) Mantle plumes from ancient oceanic crust. Earth Planet. Sci. Lett., v. 57, pp. 421-436.

Hofmann, A.W., Jochum, K.P., Seufert, M. and White, W.M. (1986) $\mathrm{Nb}$ and $\mathrm{Pb}$ in oceanic basalts: new constraints on mantle evolution. Earth Planet. Sci. Lett., v. 79, pp. 33-45.

Ionov, D.A. and Hofmann, A.W. (1995) Nb-Ta-rich mantle amphiboles and micas: implications for subduction-related metasomatic trace element fractionations. Earth Planet. Sci. Lett., v. 131, pp. 341-356.

Irvine, T.N. and Baragar, W.R.A. (1971) A guide to the chemical classification of the common rocks. Can. J. Earth Sci., v. 8, pp. 523-548.

Ito, K. and Kennedy, G.C. (1971) An experimental study of the basalt - garnet granulite - eclogite transition. Am. Geophys. Union Geophysical Monogr. 14, pp. 303-314.

Ito, K. and Kennedy, G.C. (1974) The composition of liquids formed by partial melting of eclogites at high temperatures and pressures. J. Geol., v. 82, pp. 383-392.

Jacob, D.E. (2004) Nature and origin of eclogite xenoliths from kimberlites. Lithos, v. 77, pp. 295-316.

Katz, M.B. (1978) Tectonic evolution of the Archean granulite facies belt of Sri Lanka-South India. J. Geol. Soc. India, v. 19 , pp. $185-205$.

Kent, R.W., Saunders, A.D., Kempton, P.D. and Ghose, N.C. (1997) Rajmahal basalts, eastern India: mantle sources and melt distribution at a volcanic rifted margin. In: Mahoney, J.J. and Coffin, M.F. (Eds.), Large igneous provinces: continental, 
oceanic, and planetary flood volcanism. Amer. Geophys. Union Geophys. Monogr. 100, pp. 145-182.

Klemme, S., Blundy, J.D. and Wood, B.J. (2002) Experimental constraints on major and trace elements partitioning during partial melting of eclogite. Geochim. Cosmochim. Acta, v. 66 , pp. $3109-3123$,

Kogiso, T., Tatsumi, Y. and Nakano, S. (1997) Trace element transport during dehydration processes in the subducted oceanic crust: 1. experiments and implications for the origin of ocean island basalts. Earth Planet. Sci. Lett., v. 148, pp. 193-205.

Korenaga, J. and Kelemen, P.B. (2000) Major element heterogeneity in the mantle source of the North Atlantic Igneous Province. Earth Planet. Sci. Lett., v. 184, pp. 251-268.

Krishnamurthy, P. and Cox, K.G. (1977) Picrite basalts and related lavas from the Deccan Traps of western India. Contrib. Mineral. Petrol., v. 62, pp. 53-75.

Krishnamurthy, P., Gopalan, K. and Macdougall, J.D. (2000) Olivine compositions in picrite basalts and the Deccan volcanic cycle. J. Petrol., v. 41, pp. 1057-1069.

Kuno, H. (1968) Differentiation of basaltic magmas. In: Hess, H.H. and Poldervaart, A. (Eds.), Basalts v. II., pp. 623-688. Wiley Intersci., New York.

Lightfoot, P.C., Hawkesworth, C.J., Devey, C.W., Rogers, N.W. and van Calsteren, P. W.C. (1990) Source and differentiation of Deccan Trap lavas: implications of geochemical and mineral chemical variations. J. Petrol., v. 31, pp. 1165-1200.

Le Bas, M.J., Le Maitre, R.W., Streckeisen, A. and Zanettin, B. (1986) A chemical classification of volcanic rocks based on the total alkali-silica diagram. J. Petrol., v. 27, pp. 745-750.

Macdonald, G.A. and Katsura, T. (1964) Chemical composition of Hawaiian lavas. J. Petrol., v. 5, pp. 82-133.

Mahoney, J.J. (1988) Deccan Traps. In: Macdougall, J.D. (Ed.), Continental flood basalts, Kluwer, Dordrecht, pp. 151-194.

Mahoney, J.J., Sheth, H.C., Chandrasekharam, D. and Peng, Z.X. (2000) Geochemistry of flood basalts of the Toranmal section, northern Deccan Traps, India: implications for regional Deccan stratigraphy. J. Petrol., v. 41, pp. 1099-1120.

McDonough, W.F. (1991) Partial melting of subducted oceanic crust and isolation of its residual eclogitic lithology. Phil. Trans. R. Soc. London, A 335, pp. 407-418.

McKenzie, D. and Bickle, M.J. (1988) The volume and composition of melt generated by extension of the lithosphere. J. Petrol., v. 29, pp. 625-679.

Melluso, L., Beccaluva, I., Brotzu, R., Gregnanin, A., Gupta, A.K., Morbidelli, L. and Traversa, G. (1995) Constraints on the mantle sources of the Deccan Traps from the perology and geochemistry of the basalts of Gujarat State (western India). J. Petrol., v. 36, pp. 1393-1432.

Naqvi, S.M. and Rogers, J.J.W. (1987) Precambrian Geology of India. Clarendon Press, New York.

Naqvi, S.M., Rao, V.D. and Narain, H. (1974) The protocontinental growth of the Indian shield and the antiquity of its rift valleys. Precambrian Res., v. 1, pp. 345-398.

Nicolas, A. (1989) Structures of ophiolites and dynamics of oceanic lithosphere. Kluwer, Boston.

Norton, I.O. and Sclater, J.G. (1979) A model for the evolution of the Indian Ocean and the breakup of Gondwanaland. J. Geophys. Res., v. 84, pp. 6803-6830.

O'Hara, M.J., Foulger, G.R., Herzberg, C. and Niu, Y. (2003) Mantle plumes: fertile? fecund? phantasmagorical? or simply fantastic? PIMMs anyone? Abstract in The Hotspot Handbook, Proceedings of Penrose Conference Plume IV: Beyond the Plume Hypothesis, Hveragerdi, Iceland, August 2003.

Oxburgh, E.R. and Parmentier, E.M. (1977) Compositional and density stratification in oceanic lithosphere - causes and consequences. J. Geol. Soc. London, v. 133, pp. 343-355.

Pande, K., Sheth, H.C. and Bhutani, R. (2001) ${ }^{40} \mathrm{Ar}-{ }^{39} \mathrm{Ar}$ age of the St. Mary's Islands volcanics, southern India: record of India-Madagascar break-up on the Indian subcontinent. Earth Planet. Sci. Lett., v. 193, pp. 39-46.

Peng, Z.X. and Mahoney, J.J. (1995) Drill-hole lavas from the northwestern Deccan Traps, and the evolution of Réunion hotspot mantle. Earth Planet. Sci. Lett., v. 134, pp. 169-185.

Peng, Z.X., Mahoney, J., Hooper, P., Harris, C. and Beane, J. (1994) A role for lower continental crust in flood basalt genesis? Isotopic and incompatible element study of the lower six formations of the western Deccan Traps. Geochim. Cosmochim. Acta, v. 58, pp. 267-288.

Peng, Z. X., Mahoney, J. J., Hooper, P.R., Macdougall, J.D. and Krishnamurthy, P. (1998) Basalts of the northeastern Deccan Traps, India: isotopic and elemental geochemistry and relation to south-western Deccan stratigraphy. J. Geophys. Res., v. 103, pp. 29843-29865.

Poli, S. (1993) The amphibolite-eclogite transformation: an experimental study on basalt. Amer. J. Sci., v. 293, pp. 1061-1107.

Presnall, D., Gudfinnsson, G.H. and Walter, M.J. (2002) Generation of mid-ocean ridge basalts at pressures from 1 to 7 Gpa. Geochim. Cosmochim. Acta, v. 66, pp. 2073-2090.

Radhakrishna, B.P. (1989) Suspect tectono-stratigraphic terrane elements in the Indian subcontinent. J. Geol. Soc. India, v. 34, pp. 1-24.

Richards, M.A., Duncan, R.A. and Courtillot, V.E. (1989) Flood basalts and hotspot tracks: plume heads and tails. Science, v. 246, pp. 103-107.

Roeder, P.L. and Emslie, R.F. (1970) Olivine-liquid equilibrium. Contrib. Mineral. Petrol., v. 29, pp. 275-289.

Ryerson, F.J. and Watson, E.B. (1987) Rutile saturation in magmas: implications for Ti-Nb-Ta depletion in island-arc basalts. Earth Planet. Sci. Lett., v. 86, p. 225-239.

Sen, G. (1988) Possible depth of origin of primary Deccan tholeiite magma. In: Subbarao, K.V. (Ed.), Deccan flood basalts. Geol. Soc. India Mem. No. 10, pp. 35-51.

Sen, G. (1995) A simple petrologic model for the generation of Deccan Trap magmas. Int. Geol. Rev., v. 37, pp. 825-850.

Sen, G. (2001) Generation of Deccan Trap magmas. Proc. Ind. Acad. Sci. (Earth Planet. Sci.), v. 110, pp. 409-431.

Shaw, D.M. (1970) Trace element fractionation during anatexis. Geochim. Cosmochim. Acta, v. 34, p. 237-243.

Sheth, H.C. (1999a) A historical approach to continental flood basalt volcanism: insights into pre-volcanic rifting, sedimentation, and early alkaline magmatism. Earth Planet. Sci. Lett., v. 168, pp. 19-26.

Sheth, H.C. (1999b) Flood basalts and large igneous provinces from deep mantle plumes: fact, fiction, and fallacy. Tectonophys., v. 311, pp. 1-29.

Sheth, H.C. (2000) The timing of crustal extension, diking, and the eruption of the Deccan flood basalts. Int. Geol. Rev., v. 42, pp. 1007-1016.

Sheth, H.C. (2005) From Deccan to Réunion: no trace of a mantle plume. In: Foulger, G.R., Natland, J.H., Presnall, D.C. and 
Anderson, D.L. (Eds.), Plates, plumes and paradigms. Geol. Soc. Amer. Spec. Paper, (in press).

Sheth, H.C., Mahoney J.J. and Chandrasekharam, D. (2004) Geochemical stratigraphy of Deccan flood basalts of the Bijasan Ghat section, Satpura Range, India. J. Asian Earth Sci., v. 23, pp. 127-139.

Sleep, N.H. (1984) Tapping of magmas from ubiquitous mantle heterogeneities: an alternative to mantle plumes? J. Geophys. Res., v. 89, pp. 10029-10041.

Smith, A.D. (1992) Back-arc convection model for Columbia River basalt genesis. Tectonophys., v. 207, pp. 269-285.

Smith, A.D. (1993) The continental mantle as a source for hotspot volcanism. Terra Nova, v. 5, pp. 452-460.

Stolper, E.M. and Walker, D. (1980) Melt density and the average composition of basalt. Contrib. Mineral. Petrol., v. 74, pp. 7-12.

Storey, M., Mahoney, J.J., Saunders, A.D., Duncan, R.A., Kelley, S.P. and Coffin, M. (1995) Timing of hotspot-related volcanism and the breakup of Madagascar and India. Science, v. 267, pp. 852-855.

Storey, M., Mahoney, J.J. and Saunders, A.D. (1997) Cretaceous basalts in Madagascar and the transition between plume and continental lithosphere mantle sources. In: Mahoney, J.J. and Coffin, M.F. (Eds.), Large igneous provinces: continental, oceanic, and planetary flood volcanism. Amer. Geophys. Union Geophys. Monogr. 100, pp. 95-122.

Streckeisen, A.L. (1973) Plutonic rocks, classification and nomenclature recommended by the IUGS Subcommission on the Systematics of Igneous Rocks. Geotimes, v. 18, pp. 26-30.

Subbarao, K.V. (Ed.) (1988) Deccan flood basalts. Geol. Soc. India Mem. No. 10, 393p.

Sun, S.-s. and McDonough, W.F. (1989) Chemical and isotopic systematics of oceanic basalts: implications for mantle composition and processes. In: Saunders, A.D. and Norry, M.J. (Eds.), Magmatism in the ocean basins. Geol. Soc. London Spec. Pub. No. 42, pp. 313-345.

Takahashi, E., Nakajima, K. and Wright, T.L. (1998) Origin of the Columbia River basalts: melting model of heterogeneous plume head. Earth Planet. Sci. Lett., v. 162, pp. 63-80.
Wadia, D.N., (1975) Geology of India, 4th Ed., Tata-McGraw Hill, New Delhi, 508p.

White, R.S. and McKenzie, D. (1989) Magmatism at rift zones: the generation of volcanic continental margins and flood basalts. J. Geophys. Res., v. 94, pp. 7685-7729.

White, R.S., McKenzie, D. and O'Nions, R.K. (1992) Oceanic crustal thickness from seismic measurements and rare earth element inversions. J. Geophys. Res., v. 97, pp. 19683-19715.

Wright, T.L., Mangan, M. and Swanson, D.A. (1988) Chemical data for flows and feeder dykes of the Yakima Basalt Subgroup, Columbia River Basalt Group, Washington, Oregon and Idaho, and their bearing on a petrogenetic model. U. S. Geol. Surv. Bull. 1821, 71p.

Yasuda, A., Fujii, T. and Kurita, K. (1994) Melting phase relations of an anhydrous midocean ridge basalt from 3 to $20 \mathrm{GPa}$ : implications for the behaviour of subducted oceanic crust in the mantle. J. Geophys. Res., v. 99, pp. 9401-9414.

Yasuda, A., Fujii, T. and Kurita, K. (1997) A composite diapir model for extensive basaltic volcanism: magmas from subducted oceanic crust entrained within mantle plumes. Proc. Japan Academy, v. 73, pp. 201-204.

Yaxley, G.M. (2000) Experimental study of the phase and melting relations of homogeneous basalt+peridotite mixtures and implications for the petrogenesis of flood basalts. Contrib. Mineral. Petrol., v. 139, pp. 326-338.

Yaxley, G.M. and Green, D.H. (1994) Experimental demonstration of refractory carbonate-bearing eclogite and siliceous melt in the subduction regime. Earth Planet. Sci. Lett., v. 128, pp. 313-325.

Yaxley, G.M. and Green, D.H. (1998) Reactions between eclogite and peridotite: mantle refertilisation by subduction of oceanic crust. Schweiz. Mineral. Petrogr. Mitt., v. 78, pp. 243-255.

Yoder, H.S. (1976) Generation of Basaltic Magma. National Academy of Sciences, Washington, D.C., 205p.

Yoder, H.S. and Tilley, C.E. (1962) Origin of basalt magmas: an experimental study of natural and synthetic rock systems. J. Petrol., v. 3, pp. 342-532.

Zhang, S.-Q., Mahoney, J.J., Mo, X.-X., Ghazi, A.M., Milani, L., Crawford, A.J. and Guo, T.-Y. (2004) Evidence for a widespread Tethyan upper mantle with Indian-Ocean-type isotopic characteristics. J. Petrol. (in press). 